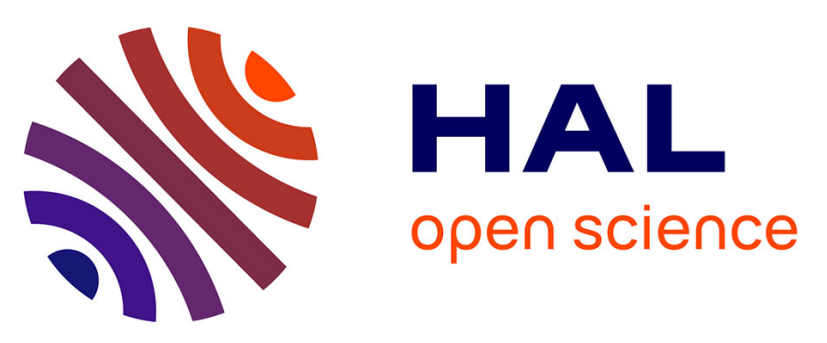

\title{
History of Subduction Polarity Reversal During Arc-Continent Collision: Constraints From the Andaman Ophiolite and its Metamorphic Sole
}

Alexis Plunder, Debaditya Bandyopadhyay, Morgan Ganerod, Eldert L Advokaat, Biswajit Ghosh, Pinaki C Bandopadhyay, Douwe J van Hinsbergen

\section{To cite this version:}

Alexis Plunder, Debaditya Bandyopadhyay, Morgan Ganerod, Eldert L Advokaat, Biswajit Ghosh, et al.. History of Subduction Polarity Reversal During Arc-Continent Collision: Constraints From the Andaman Ophiolite and its Metamorphic Sole. Tectonics, 2020, 10.1029/2019TC005762 . hal02733950

\section{HAL Id: hal-02733950 https: / hal-brgm.archives-ouvertes.fr/hal-02733950}

Submitted on 2 Jun 2020

HAL is a multi-disciplinary open access archive for the deposit and dissemination of scientific research documents, whether they are published or not. The documents may come from teaching and research institutions in France or abroad, or from public or private research centers.
L'archive ouverte pluridisciplinaire HAL, est destinée au dépôt et à la diffusion de documents scientifiques de niveau recherche, publiés ou non, émanant des établissements d'enseignement et de recherche français ou étrangers, des laboratoires publics ou privés. 


\section{Tectonics}

\section{RESEARCH ARTICLE 10.1029/2019TC005762 \\ Special Section: \\ Tethyan dynamics: from rift- ing to collision}

Key Points:

- We document the condition of formation of the metamorphic sole of the Andaman Island ophiolite

- We provide $\mathrm{Ar} / \mathrm{Ar}$ ages for the subduction initiation leading to the formation of the Andaman Island ophiolite

- We estimate the duration of subduction polarity reversal following an arc-continent collision to $10 \mathrm{Myr}$ at least

Supporting Information: - Supporting Information S1

Correspondence to:

A. Plunder,

a.plunder@brgm.fr

Citation:

Plunder, A., Bandyopadhyay, D. Ganerød, M., Advokaat, E. L., Ghosh, B., Bandopadhyay, P., \& van Hinsbergen, D. J. J. (2020). History of subduction polarity reversal during arc-continent collision: Constraints from the Andaman ophiolite and its metamorphic sole. Tectonics, 39, e2019TC005762. https://doi.org/ 10.1029/2019TC005762

Received 12 JUL 2019 Accepted 6 MAR 2020 Accepted article online 10 MAR 2020

(C)2020. American Geophysical Union. All Rights Reserved.

\section{History of Subduction Polarity Reversal During Arc-Continent Collision: Constraints From the Andaman Ophiolite and its Metamorphic Sole}

\author{
Alexis Plunder ${ }^{1,2}$ iD, Debaditya Bandyopadhyay ${ }^{3,4}$ iD, Morgan Ganerød ${ }^{5}$, Eldert L. Advokaat ${ }^{1,6}$ iD, \\ Biswajit Ghosh $^{3}$, Pinaki Bandopadhyay ${ }^{3}$, and Douwe J. J. van Hinsbergen ${ }^{1}$ \\ ${ }^{1}$ Department of Earth Sciences, Utrecht University, Utrecht, the Netherlands, ${ }^{2}$ BRGM, Orléans, France, ${ }^{3}$ Department of \\ Geology, University of Calcutta, Kolkata, India, ${ }^{4}$ Department of Geology, University of North Bengal, Darjeeling, India, \\ ${ }^{5}$ Geological Survey of Norway NGU, Trondheim, Norway, ${ }^{6}$ Department of Physical Geography, Utrecht University, \\ Utrecht, the Netherlands
}

\begin{abstract}
Subduction polarity reversal during arc-continent collision has been proposed as a key mechanism to initiate new subduction zones. Despite often interpreted, well-exposed geological record that document the reversal is sparse. The ophiolitic lithounits of the Andaman and Nicobar Islands have been proposed to have formed during the initiation of a new subduction zone following the collision of the Woyla Arc of Sumatra with Sundaland (Eurasia). We here present new field, petrological and geochronological data to evaluate the timing of the initiation of Andaman subduction. We targeted the previously inferred but unstudied metamorphic sole of the Andaman ophiolites that witnessed juvenile subduction. Thermodynamic modeling reveals that the exposed amphibolites of the sole formed at around $0.9 \mathrm{GPa}$ and $675^{\circ} \mathrm{C}$. We dated two samples of the metamorphic sole using the Ar/Ar method on amphibole, giving cooling ages of $106.4 \pm 2.1$ and $105.3 \pm 1.6 \mathrm{Ma}$. This is similar to published ages from plagioclase xenocrysts in recent Barren Island volcanics and in zircons from a gabbro sample from the Andaman ophiolite, which we interpret as the age of the original ophiolite formation. The Ar/Ar ages are considerably older than arc magmatic gabbros and plagiogranites of the overlying ophiolite previously dated at 99-93 Ma and thought to reflect the ophiolite age but recently reinterpreted as a volcanic arc built on the ophiolite. Combined with the ages of Woyla-Sundaland collision, we argue that subduction polarity reversal occurred in a transient period of perhaps some $10 \mathrm{Myr}$, similar to recent settings.
\end{abstract}

\section{Introduction}

The formation of new subduction zones is critical in the plate tectonic cycle. A fundamental way in which new subduction zones form is through subduction polarity reversal following arc-continent collision (e.g., Chemenda et al., 2001; Dewey, 1976; Faccenda et al., 2008; Pysklywec, 2001; Stern, 2004; Stern \& Gerya, 2017) where upon ongoing convergence, the arrest of one subduction zone is followed by the initiation of another, typically within or behind the older arc (Figure 1). The arrest of the older subduction zone is then often related to arrival of buoyant continental or thickened oceanic lithosphere on the original downgoing plate in the trench. For instance, the arrival of the Ontong-Java Oceanic Plateau in the Vitiaz Trench led to the formation of the New Hebrides subduction zone in the Vitiaz/Melanesian Arc (Hall, 2002; Knesel et al., 2008). Subduction polarity reversal following arc-continent collision was also proposed in the Aleutian Arc (Vaes et al., 2019) or to form the modern Kamchatka subduction zone (Domeier et al., 2017; Konstantinovskaia, 2001; Shapiro \& Solov'ev, 2009; Vaes et al., 2019). Modern examples where polarity reversal may be ongoing are the Banda Arc in Timor (e.g., Breen et al., 1989; Harris, 2006; Tate et al., 2015), Taiwan (Chemenda et al., 2001), or the Solomon Arc (Cooper \& Taylor, 1985; Cooper \& Taylor, 1987). Despite the widespread recognition of arc polarity reversal in the geological record, the dynamics and longevity of the reversal process are poorly known. The duration of polarity reversal, that is, the time between subduction stops upon arc-continent collision and the time at which the new subduction is fully developed (see Figure 1) is however not known from direct evidences. Estimating the kinematic history of the transition requires a geological record that allows dating the arrest of the old subduction (ceasing of the arc) and the beginning of the new one, which is challenging given the destructive nature of active margins. 


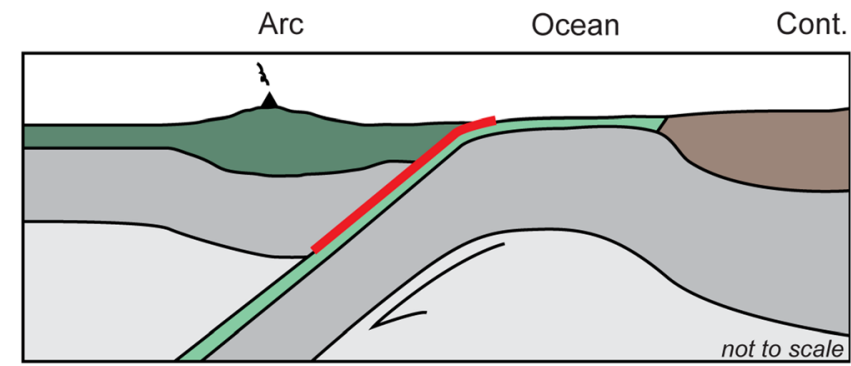

Cont. Arc collision
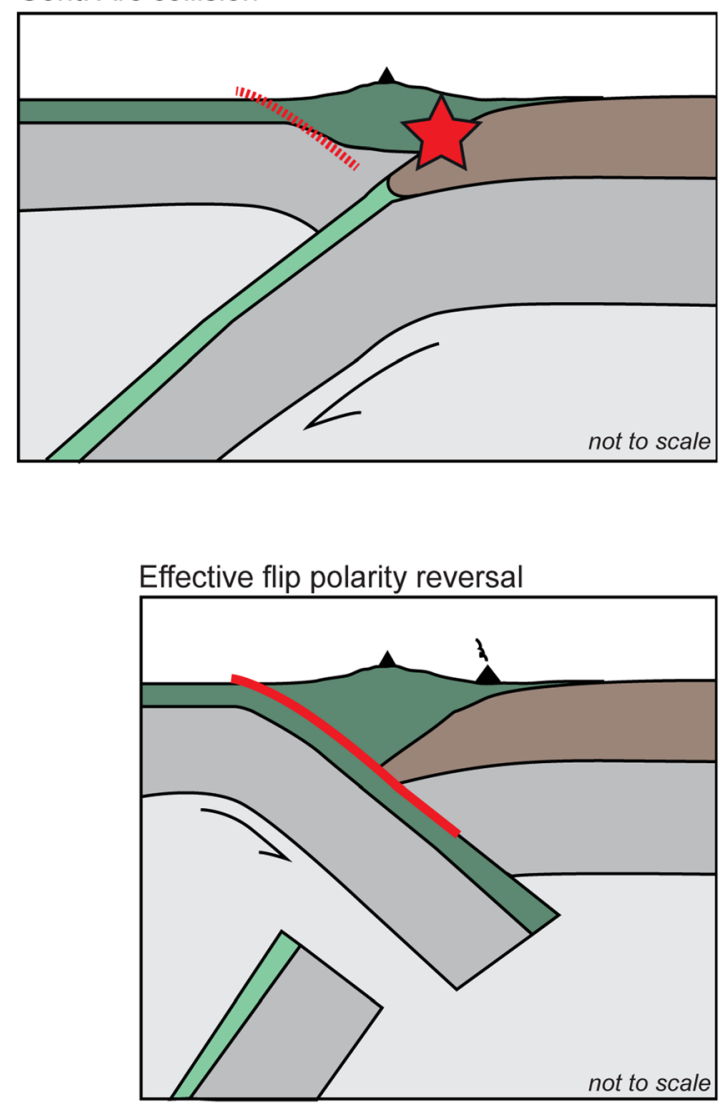

Figure 1. Conceptual sketch of subduction polarity reversal. The first stage depicts oceanic subduction below a mature arc. The red lines show the subduction interface where one lithosphere slides against the other one. The second sketch depicts the continent entering the subduction zone, and the red star emphasizes the collision between the continent and the arc. The dashed red line shows the mechanically weak place where the new subduction will start. The third cartoons show the effective subduction polarity reversal. The red lines again show the subduction interface where one lithosphere slides against the other one. The cartoon is inspired by Chemenda et al. (2001).
The ophiolitic sequence of the Andaman Islands in the eastern Indian Ocean, however, may preserve such a record. The Andaman and Nicobar Archipelago is located in the forearc of the Sunda-Sumatra subduction zone (Figures $2 \mathrm{a}$ and $2 \mathrm{~b}$ ). It exposes a thrusted sequence of variably depleted and chromitite-bearing peridotites. The peridotites are overlain by mafic magmatic rocks and underlain by a serpentinite-hosted mélange that contains sheared greenschist- and amphibolite-facies blocks, as well as radiolarian chert blocks with stratigraphic ages up to the middle Eocene (Bandopadhyay \& Carter, 2017a; Bandyopadhyay et al., 2020; Ghosh et al., 2009, 2017; Ling et al., 1996; Sengupta et al., 1990). The ophiolitic rocks are unconformably overlain by Paleocene to Eocene shallow-marine sandstones derived from a volcanic arc, and after the middle Eocene, the sequence thrusted and tectonically repeated (Bandopadhyay \& Carter, 2017b).

The variably depleted peridotites and the magmatic sequence of the ophiolites have long been considered to represent one coherent but tectonically dismembered suprasubduction zone (SSZ) ophiolite sequence, (i.e., an ophiolite with an arc signature but with a structure of oceanic lithosphere; Pearce et al., 1984; Stern, 2004; for the Andaman ophiolite, see Ghosh et al., 2009; Pal, 2011; Pedersen et al., 2010). Magmatic rocks in the sequence include in places plagiogranites (trondhjemites) and are overlain by Upper Cretaceous (Campanian) radiolarian cherts (Ling et al., 1996). Whole rock $\mathrm{Sm} / \mathrm{Nd}$ ages on different component of the ophiolite (basalt, plagiogranite and peridotite) yielded a $98 \pm 8.2 \mathrm{Ma}$ isochron (Bhattacharya et al., 2020). Two trondhjemites samples gave zircon $\mathrm{U} / \mathrm{Pb}$ ages of of $93.6 \pm 1.3 \mathrm{Ma}$ (Sarma et al., 2010) and $95 \pm 2 \mathrm{Ma}$ (Pedersen et al., 2010) that were interpreted to represent the formation of Andaman ophiolite crust above a subduction zone. Whereas Pedersen et al. (2010) interpret them to represent subduction initiation, other authors argue a geochemical signature typical of a mature arc rather than an SSZ fore-arc setting (Jafri et al., 1995; Sarma et al., 2010). Near Chiriyatapu, trondhjemites are found as blocks in an andesitic agglomerate. The agglomerates display arc characteristics (explosive intermediate volcanism) and are generally found overlying the ophiolite. In the field, the absence or really minor presence of any other ophiolitic clasts (i.e. basalt, peridotite), and their disposition suggest that they are cogenetic with the andesites. Combined, these data show that there has been at least $5 \mathrm{Myr}$ of magmatism with a diverse geochemical signature, suggesting an arc setting for parts of the Andaman ophiolites. Finally, thin ash layers within Upper Cretaceous radiolarian cherts that intercalate with pillow lavas of South Andaman also suggest that there was explosive volcanism during or not long after the magmatic sequence of the ophiolite formed (Jafri et al., 2006).

Both the 5-Myr age range as well as the broad range of geochemical signature and composition of the volcanics of the Andaman ophiolite are surprising (Ghosh et al., 2017). SSZ ophiolites are typically found in fore-arc settings where they form during incipient upper plate extension following subduction initiation (e.g., Guilmette et al., 2018; Stern et al., 2012). Mature volcanic arcs occur at a distance of typically $~ 100-300 \mathrm{~km}$ away from the trench (Dickinson, 1973) with an average around $166 \pm 66 \mathrm{~km}$ (Gill, 1981) or between 180 and $275 \mathrm{~km}$ (Syracuse \& Abers, 2006). The juxtaposition of the SSZ forearc and arc may thus require tectonic motion from a forearc to a back-arc domain or that SSZ spreading occurred within a mature arc setting. In the relatively restricted area of the Andaman Islands $(350 \times 40 \mathrm{~km})$, it is surprising to find a 5-Myr duration at least for magmatism since already formed crust moves at half-spreading rate from the spreading centers. Typical magmatic 

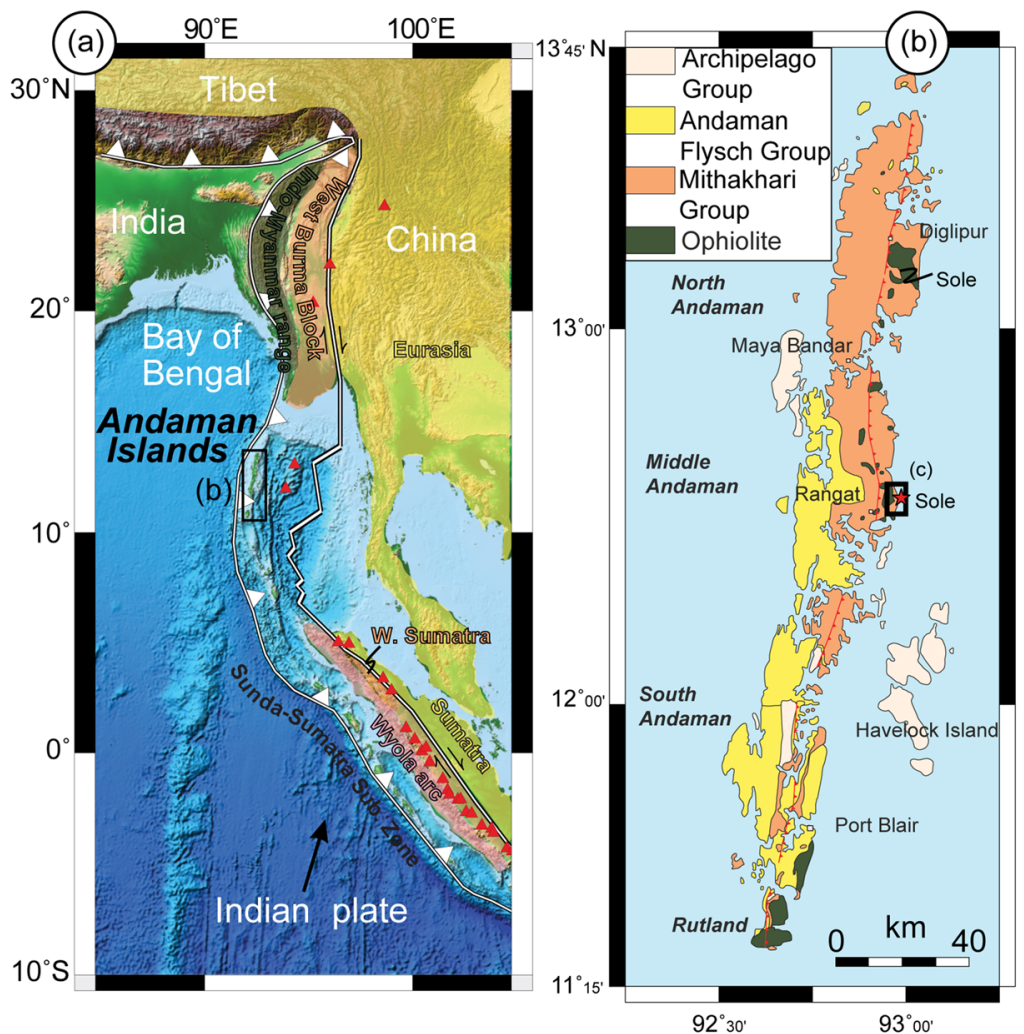

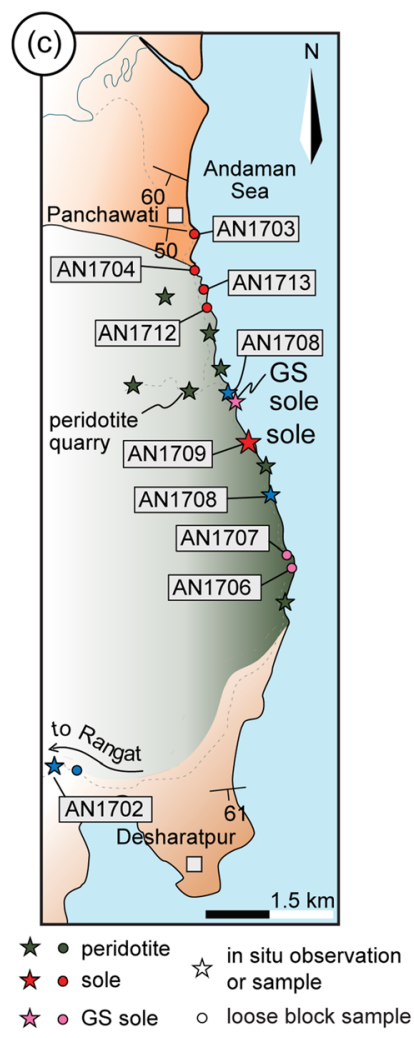

is $\circ$ GS sole

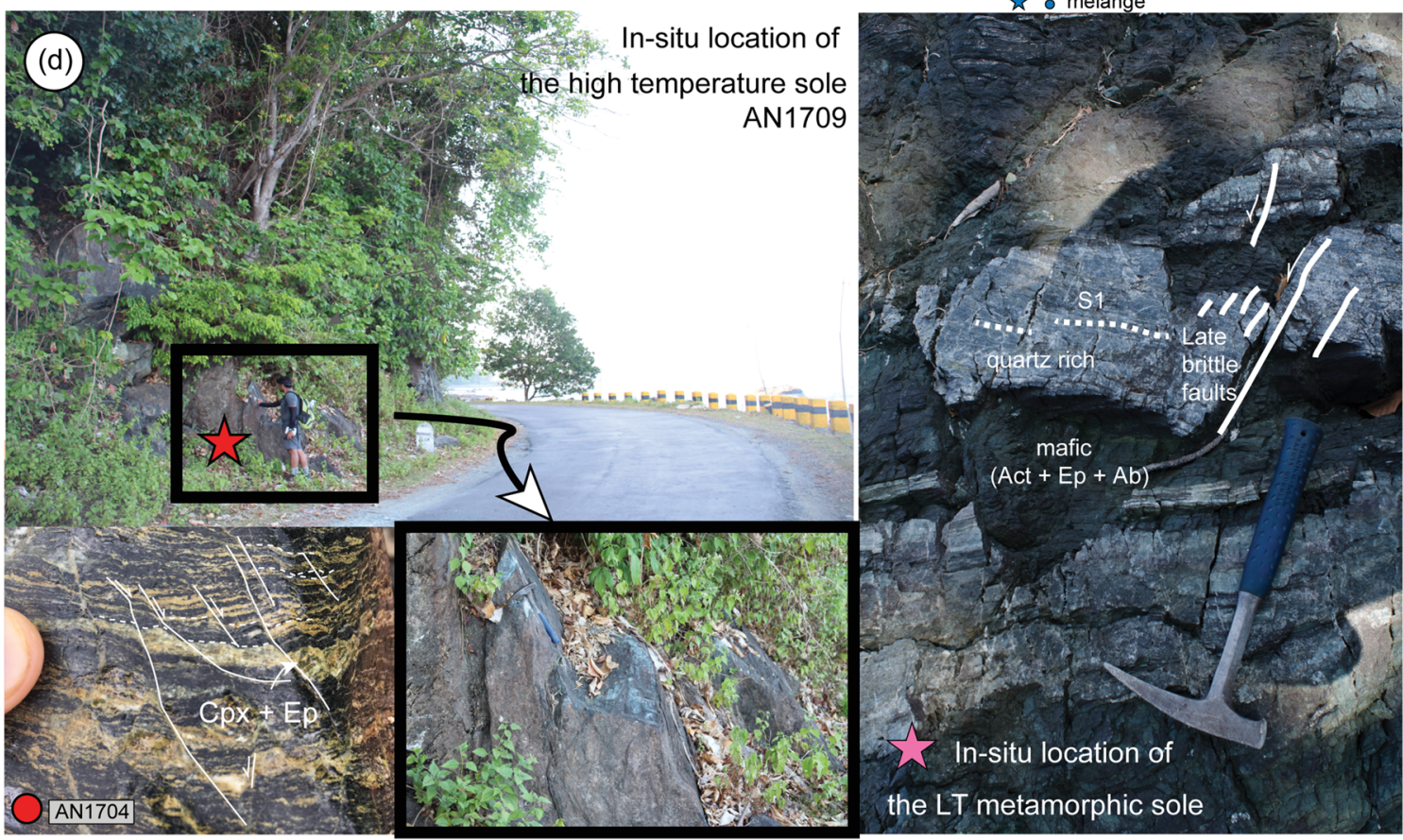

Figure 2. (a) Location of the Andaman Island in the Indian Ocean realm (modified from Ghosh et al., 2017). (b) Schematic geological map of the Andaman Islands modified from Ghosh et al. (2017). (c) Sketch of the investigated area redrawn from field observation. Color of the symbols denotes the nature of the rock. The shape of the symbol denotes the character of the observation/sample: in situ of flying blocks. (d) Field view of the in situ clinopyroxene-bearing amphibolite (AN1709a sample). The red star refers to the position of sample AN1709 on the localization map. Both insets show more detailed picture on the in situ location and of a boulder (sample AN1704). The right panel shows the in situ location of the greenschist-facies metamorphic sole characterized by the alternation of mafic and quartz-rich layers. The pink star refers to the position on the map. Mineral abbreviations are after Whitney and Evans (2010). 
spreading rates are of several tens of kilometer per million years. It means that the ages of magmatic rocks in narrow ophiolite bodies like on Andaman are typically within 1-2 Myr (e.g., in Oman, Rioux et al., 2016, 2013; or Turkey, van Hinsbergen et al., 2016; and reference therein; Parlak et al., 2019). Instead, the minimal 5-Myr transition between SSZ and arc magmatism that are found within a few meters in Andaman suggests a more or less stationary magma source after the SSZ ophiolite is formed. After it formed around $93 \mathrm{Ma}$, the arc is believed to be active at least until the Paleocene to Eocene as attested by arc-derived sandstone (Bandopadhyay, 2012).

Advokaat et al. (2018) recently suggested that when corrected for post-Cretaceous tectonic motion along the Sunda forearc, the Andaman ophiolites restore adjacent to and west of the extinct intraoceanic Woyla Arc that is now located on Sumatra and West Java. This arc collided with the Sundaland margin in the late Cretaceous. Advokaat et al. (2018) postulated that the Andaman SSZ ophiolites may have formed during a subduction polarity reversal within or adjacent to the Woyla Arc upon its collision with Sundaland. In this paper, we study sheared amphibolites below the Andaman ophiolite that are interpreted as their metamorphic sole (Pal \& Bhattacharya, 2010). Metamorphic soles are slivers of oceanic crust stripped of the downgoing slab that are formed and underplated beneath the mantle wedge during subduction infancy. They form during subduction initiation (Wakabayashi \& Dilek, 2000) over a short time span (typically of 1-2 Myr) and cool coevally to the formation of SSZ ophiolite (Hacker, 1994; Rioux et al., 2016). Worldwide, they share very similar characteristic: they are formed in a warm thermal regime, up to melting condition $\left(850{ }^{\circ} \mathrm{C}\right.$ and $1.2 \mathrm{Gpa}$ ), in a much higher thermal regime than expected for a mature subduction zone (Agard et al., 2016; Dubacq et al., 2019; Jamieson, 1986; Soret et al., 2017; Wakabayashi \& Dilek, 2003; Woodcock \& Robertson, 1977). They comonly have a 10- to 500-m thickness in total, and parts with different peak metamorphic grades represent different tectonics slices. The higher temperature part of the sole is made of mafic oceanic crust. The lower parts tend to show an increase of a sedimentary component (Casey \& Dewey, 1984). Cooling ages of metamorphic soles (i.e., obtained by the Ar/Ar method on amphibole) are globally strongly correlated to the age of the crust of the overlying SSZ ophiolites, suggesting that decompression and exhumation of soles are the result of upper plate spreading (Dewey \& Casey, 2013; van Hinsbergen et al., 2015). Such cooling ages may thus serve as a proxy for the age of the SSZ ophiolite spreading (or hyperextension). However, they provide only a minimum age for the initiation of subduction, which may predate SSZ spreading by $\sim 10 \mathrm{Myr}$ or more as recently shown by Lu-Hf garnet ages in soles (Guilmette et al., 2018; Pourteau et al., 2019).

The metamorphic sole are found below the ophiolites on Middle and North Andaman Islands (Figures 2a-2c). We establish the pressure-temperature (PT) condition at which they formed using empirical thermobarometry and pseudosection modeling. We provide Ar/Ar ages to establish their cooling as proxy for the timing of SSZ ophiolite formation. We finally discuss our results in terms of temporal and spatial relationships between SSZ ophiolite evolution, magmatic evolution, and subduction polarity reversal dynamics.

\section{Geological Setting}

\subsection{Regional Setting of the Andaman-Nicobar Islands}

The Andaman and Nicobar Islands are located at the northernmost extension of the present-day Sunda-Sumatra subduction system where the Indo-Australian Plate is subducting below Eurasia (Figure 2a; Curray, 2005, 1989; McCaffrey, 1992, 2009). To the east of the Andaman and Nicobar Islands is the Andaman Sea, an approximately N-S spreading, Neogene pull-apart basin that formed in the back-arc region of the Andaman subduction zone as a result of formation of the Burma-Andaman fore-arc sliver, partitioning highly oblique India-Sundaland convergence over a trench in the west and a transform system in the east (Curray, 2005). Restoring the opening of this basin brings the Cretaceous-Paleogene rock record of the Andaman Islands toward the south, juxtaposed in Oligocene time against West Sumatra (Curray, 2005).

On West Sumatra lies the accreted, formerly intraoceanic Woyla volcanic arc. This arc formed in earliest Cretaceous time within the Neotethys ocean (Hall, 2012). Paleomagnetic data from the Woyla Arc give paleolatitudes that are consistent with the arc having formed on the Australian Plate that until the 
Eocene moved eastwards relative to Eurasia (Advokaat et al., 2018). Midlate Cretaceous collision of the Woyla Arc with Sundaland may have occurred diachronously from north to south, and ongoing Australia-Eurasia motion likely triggered a subduction polarity reversal recorded in the Indo-Myanmar and Andaman ophiolites (Advokaat et al., 2018).

Regionally, remnants of oceanic lithosphere are preserved as ophiolite, generally described as tectonically dismembered along the Indo-Myanmar suture zone (Fareeduddin \& Dilek, 2015; Liu et al., 2016; Singh et al., 2017). The Andaman ophiolites are arguably the most complete in the sense that ultramafic and mafic sequences are present (Ghosh et al., 2014, 2017; Pal, 2011; Pal et al., 2003), although as described above, these may not, or not entirely, be cogenetic (i.e. gabbro intruding plagiogranite; Bhattacharya et al., 2020). Metamorphic rocks were described from the serpentinite-hosted subophiolitic mélange and were suggested to reflect parts of a dismembered metamorphic sole (Pal \& Bhattacharya, 2010), but their precise metamorphic conditions, or the age of formation and/or cooling, are so far unconstrained.

\subsection{The Andaman Ophiolite}

The tectonostratigraphy of the Andaman Islands has been discussed in detail in Bandopadhyay (2012). The ophiolite contains a coherent mantle sequence mainly made of variably serpentinized peridotite (tectonized harzburgite or lherzolite with chromitite and dunite pods) with in places layered gabbros with local plagiogranite intrusions (Ghosh et al., 2014, 2017; Jafri et al., 1995; Pal, 2011; Saha et al., 2010). Ophiolitic rocks crop out well along the eastern shore line of Rutland Island and South, Middle, and North Andaman Islands (Figure 2b). Plagiogranite from South Andaman yielded the $93.6 \pm 1.3 \mathrm{Ma} \mathrm{U} / \mathrm{Pb}$ zircon age mentioned above (Sarma et al., 2010) and the $95 \pm 2 \mathrm{Ma} \mathrm{U} / \mathrm{Pb}$ age (Pedersen et al., 2010). In South Andaman, volcanic and volcanoclastic rocks are divided in two groups based on field disposition and geochemical characters (Pillow lava and East Coast volcanics after Ray, 1985; Ray et al., 1988) made of basalt and andesite with local felsic differentiates. The rocks of the crustal section show a progressive evolution from a midocean ridge to SSZ affinity (Ghosh et al., 2017). The East Coast volcanics, reported from South Andaman, are cogenetic with gabbro from the Moho transition zone and have an arc affinity (Ghosh et al., 2014). On top of the sequence, we found some hemipelagic sediments interbedded with basaltic layers. The sequence is assigned to the Upper Cretaceous on the basis of fossil assemblages (Ling et al., 1996; Ling \& Srinivasan, 1993; Pal et al., 2003; Roy et al., 1988). Also, middle Eocene radiolarian cherts are found in an isolated outcrop in southern South Andaman (Ling et al., 1996; Ling \& Srinivasan, 1993). Because the Eocene sediments above the Andaman ophiolites are shallow-marine volcanic arc-derived sandstones (Bandopadhyay \& Carter, 2017b), there are likely part of the accretionary mélange underneath the ophiolite. Following the accretion of the youngest, Eocene, radiolarian chert to the mélange, the ophiolite and overlying fore-arc sediments were thrusted and tectonically repeated (Pal et al., 2003). This may coincide with the underthrusting of a seismically imaged crustal block of possibly continental composition currently residing in the crust below the Andaman ophiolite (Ghosh et al., 2017; Ratheesh Kumar et al., 2013; Singh et al., 2013).

\subsection{The Andaman Islands Metamorphic Sole}

The metamorphic rocks of the Andaman Islands have been investigated by Pal and Bhattacharya (2010). They described two main localities in North and Middle Andaman. In North Andaman, the metamorphic rocks are described as isolated small bodies below tectonized peridotite. In Middle Andaman, they are described as allochthonous bodies within the mélange unit. The localities are characterized by metabasites and metasediments, both described as metamorphosed in the greenschist facies (Pal \& Bhattacharya, 2010), but the metamorphic grade has not been evaluated quantitatively. Geochemistry of the metabasites gives an alkaline basalt protolith, and the timing of formation was bracketed between the Cretaceous and the Oligocene (Pal \& Bhattacharya, 2010). Geochemically, the sole rocks show a subduction influenced origin (Pal \& Bhattacharya, 2010) Sample AN1703 that is a quartz-rich sample interpreted to be a metachert has also an arc influence. 


\section{Field Observations, Sampling, and Petrography}

\subsection{Field Observation and Sampling}

Strongly foliated and sheared greenschist- to amphibolite-facies rocks are found along the eastern coast of Middle Andaman in the region of Panchawati RV (Figure 2c). Apart from one in situ location where foliated amphibolites are found welded to basal peridotites of the ophiolite (Figures $2 \mathrm{c}$ and $2 \mathrm{~d}$ and Table 1) these rocks occur as large, angular, loose boulders on the beach with sizes up to $10 \mathrm{~m}$ or more, suggesting they were likely not displaced over large distances. These metamorphic blocks are found along an approximately 3-km long strip of beach. Far away $(1 \mathrm{~km})$ from the in situ location, the blocks decrease in size to pebbles and cobbles. The metamorphic rocks are dominated by dark layered mafic amphibolite with feldspar, amphibole, and clinopyroxene. Sometimes late epidote is visible with the naked eye. The foliation is well defined, but mineral lineation is not obvious probably due to the scattered recrystallization of amphibole. The foliation is cross cut by late mineral filling in brittle cracks (Figure 2d). We also observed greenschist-facies rocks that occur along shore (Figure 2c). They consist in the field of coherent, tens of meter sized blocks with metacherts interbedded with greenschist-facies metavolcanics (Figure 2d). We also investigated the Kalighat location on North Andaman previously described by Pal and Bhattacharya (2010). This locality shows 10-m sized blocks of metaquartzite and phyllites outcropping in the jungle without clear relation to the surrounding ultramafic rocks. We collected about 20 samples of the metamorphic sole and the above mélange. Most of the samples come from the main metamorphic sole locality along the coast of Middle Andaman (Figure 2c; Table 1).

\subsection{Summary of Microscopic Observations}

We here describe in detail the characteristic of our samples. As most samples are similar, we provide a generic description. Specific description of samples analyzed at the microprobe are given in supporting information Appendix S1. All samples were cut in the $x z$ plane of finite deformation except when a penetrative deformation was not observable. In the last case, the samples were cut perpendicular to the foliation.

Most of the amphibolite facies rocks have a nematoblastic texture. The foliation is defined by the elongation of amphibole alternating with plagioclase. Green amphibole coexisting with plagioclase constitutes the dominant minerals (Figure 3). We observed amphibole- and feldspar-rich layers with a thickness varying from 0.1 to $5 \mathrm{~mm}$ between samples. In general, the amphibole is pristine, whereas the plagioclase often shows destabilization texture to a fine-grained mixture of epidote and albite (Figure $3 \mathrm{~m}$ ). We found clinopyroxene in three samples (Figures 3b, 3d, 3j, 3k, 3n, and 3o; Table 1). It occurs as relict grains partially replaced by amphibole and indicates a peak metamorphic assemblage composed of clinopyroxene + amphibole + plagioclase + a Ti-bearing phase. We also observed inclusion of amphibole in clinopyroxene emphasizing their coexistence (Figure 3d). Titanium-bearing phases (titanite, rutile, and ilmenite) are present as accessory minerals in all samples (Figure 3). They show complex relations (Figures 3e, 3f, 3g, 3i, 3j, 3k, and 3l) and detailed observation (scanning electron microscope and reflected light) show that rutile is generally the first phase to crystalize. It is overgrown/rimmed by ilmenite (Figure 3i) and/or titanite (Figures 3f, 3g, 3j, and 31). In most samples, we find rutile present as inclusion within titanite. We interpret the rutile to represent the peak metamorphism condition. In some cases, rutile coexists with ilmenite (e.g., in sample An1709a). In a few samples, we found epidote present as late crystals (Table 1). Apatite, chlorite, and pyrite are minor components of some samples (Table 1). In addition, our samples show late-stage (possibly hydrothermal) alteration features, with adularia (Figure $3 \mathrm{~h}$ ) and calcite in cross-cutting veins. Epidote and green amphibole also grow in such veins (Figures $3 \mathrm{~b}$ and $3 \mathrm{~h}$ ).

Greenschist-facies rocks are made of green amphibole, plagioclase, and epidote (Table 1). Elongated light-green amphibole marks the foliation. Epidote is either present as porphyroblast within the foliation or as layers marking the foliation. It is at textural equilibrium with plagioclase and amphibole. Quartz-rich samples share the same mineral assemblage but have a different texture. In places, we observed chlorite growing together with the abovementioned minerals. In all samples, late calcite or adularia veins cross cut the main fabric, similar to the amphibolite facies rocks. The Ti-bearing phase is either rutile overgrown by titanite or only titanite.

We also collected two samples from the Kalighat area in North Andaman previously described by Pal and Bhattacharya (2010). They consist of quartz, white mica, epidote, and opaque minerals. The samples 
Table 1

Sample List, Location, and Mineral Occurrences

\begin{tabular}{|c|c|c|c|c|c|c|c|c|c|c|c|c|c|c|}
\hline \multirow{2}{*}{$\begin{array}{l}\text { Sample } \\
\text { code }\end{array}$} & \multicolumn{2}{|c|}{ Location (WGS 84) } & \multirow[b]{2}{*}{ Grade } & \multirow[b]{2}{*}{ Amph } & \multirow[b]{2}{*}{$\mathrm{Plg}$} & \multirow[b]{2}{*}{ Cpx } & \multirow[b]{2}{*}{ Ep } & \multirow[b]{2}{*}{ Rt } & \multirow[b]{2}{*}{ Ttn } & \multirow[b]{2}{*}{$\mathrm{Ilm}$} & \multirow[b]{2}{*}{ Ad } & \multirow[b]{2}{*}{ Other } & \multirow[b]{2}{*}{ Other } & \multirow[b]{2}{*}{ Other } \\
\hline & $\mathrm{N}\left({ }^{0}, \prime \prime\right)$ & $\mathrm{E}\left({ }^{\circ} \prime \prime \prime\right)$ & & & & & & & & & & & & \\
\hline AN1702 & 123027 & 0925619 & Mélange & & & & & & & & & & & \\
\hline AN1703 & 123544 & 0925727 & $\mathbf{A}$ & $\mathbf{x}$ & $\mathbf{x}$ & & (P1) & $\mathbf{x}$ & *'(Rt) & ${ }^{*}(\mathbf{R t})$ & ${ }^{*}(\mathbf{v})$ & ${ }^{*}$ Amp (Amp) & ${ }^{*}$ Mus (P1) & Qz \\
\hline AN1704a & 123527 & 0925728 & $\mathbf{A}$ & $\mathbf{x}$ & $\mathbf{x}$ & $\mathbf{x}$ & (P1) & $\mathbf{x}$ & ${ }^{*}(\mathbf{R t})$ & $?$ & * (v) & ${ }^{*}$ Amp (Amp) & & \\
\hline AN1704b & 123527 & 0925728 & $\mathbf{A}$ & $\mathbf{x}$ & $\mathbf{x}$ & & $\mathrm{x} /{ }^{*}(\mathrm{Pl})$ & $\mathbf{x}$ & $\mathbf{x} /{ }_{*}^{*}(\mathbf{R t})$ & & (v) & Amp (Amp) & * Mus (Pl) & \\
\hline AN1706a & 123231 & 0925831 & GS & $\mathrm{x}$ & $\mathrm{x}$ & & $\mathrm{x}$ & $\mathrm{x}$ & $\mathrm{x} /{ }^{*}(\mathrm{Rt})$ & & & & & \\
\hline AN1706b & 123231 & 0925831 & GS & $\mathbf{x}$ & $\mathbf{x}$ & & $\mathbf{x}$ & $\mathrm{x}$ & $\mathrm{x} /{ }^{*}(\mathrm{Rt})$ & & ${ }^{*}(\mathrm{v})$ & & & \\
\hline AN1707a & 123238 & 0925830 & GS & $\mathbf{x}$ & $\mathbf{x}$ & & $\mathbf{x}$ & & $\mathbf{x}$ & & ${ }^{*}(\mathrm{v})$ & ${ }^{*} \mathrm{Cc}(\mathrm{v})$ & & \\
\hline AN1707b & 123238 & 0925830 & GS & & $\mathbf{x}$ & & $\mathbf{x}$ & & & & (v) & $\mathrm{Cc}(\mathrm{v})$ & Chl Opq & Qz \\
\hline AN1708 & 123315 & 0925818 & Mélange & & & & & & & & & & & \\
\hline AN1709a & 123344 & 0925807 & $\mathbf{A}$ & $\mathbf{x}$ & $\mathbf{x}$ & $\mathbf{x}$ & ${ }^{*} /{ }^{*}(\mathrm{Pl})$ & $\mathbf{x}$ & * (Rt) & & & ${ }^{*}$ Chl & & \\
\hline AN1709b & 123344 & 0925807 & $\mathbf{A}$ & $\mathbf{x}$ & $\mathbf{x}$ & & ${ }^{*}(\mathrm{Pl})(\mathrm{v})$ & $\mathbf{x}$ & * $\mathbf{x}$ & & (v) & & & \\
\hline AN1709c & 123344 & 0925807 & A & $\mathrm{x}$ & $\mathrm{x}$ & & & $\mathrm{x}$ & ${ }_{*}^{*}(\mathrm{Rt})$ & ** $(\mathrm{Rt})$ & & *Amp (Amp) & & $\mathrm{Qz}$ \\
\hline AN1709d & 123344 & 0925807 & $\mathbf{A}$ & $\mathbf{x}$ & $\mathbf{x}$ & & $\mathbf{x}$ & $\mathbf{x}$ & ${ }^{*}(\mathrm{Rt})$ & & & Bt? & ${ }^{*} \mathrm{Chl}$ (Bt?) & \\
\hline AN1709e & 123344 & 0925807 & $\mathbf{A}$ & (cpx) & $\mathbf{x}$ & $\mathbf{x}$ & $\mathrm{x} /{ }^{*}(\mathrm{Pl})$ & & $\mathbf{x}$ & & & Ce & Opq & \\
\hline AN1712a & 123541 & 0925741 & A & $\mathrm{x}$ & $\mathrm{x}$ & & & & & & (v) & Amp (Amp) & & \\
\hline AN1712b & 123541 & 0925741 & A & $\mathrm{x}$ & $\mathrm{x}$ & & *(v) & & & & (v) & Amp (Amp) & & \\
\hline AN1713a & 123516 & 0925734 & $\mathbf{A}$ & $\mathbf{x}$ & $\mathbf{x}$ & & & $\mathbf{x}$ & $\mathrm{x} /{ }_{*}^{*}(\mathrm{Rt})$ & & ${ }_{*}^{*}(\mathbf{v})$ & & ${ }_{*}^{*} \operatorname{Mus}(\mathrm{Pl})$ & \\
\hline AN1713b & 123516 & 0925734 & A & $\mathrm{x}$ & $\mathrm{x}$ & & $\mathrm{x}$ & $\mathrm{x}$ & $\mathrm{x} /{ }^{*}(\mathrm{Rt})$ & & (v) & Amp (Amp) & ${ }^{*} \operatorname{Mus}(\mathrm{Pl})$ & \\
\hline AN1713c & 123516 & 0925734 & A & $\mathrm{x}$ & $\mathrm{x}$ & & * $(\mathrm{Pl})$ & *(ilm) & ${ }^{*}(\mathrm{ilm})$ & $\mathrm{x}$ & & & ${ }^{*}$ Mus (Pl) & \\
\hline
\end{tabular}

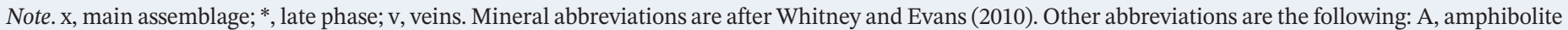
facies; GS, greenschist facies. Lines in bold correspond to sample for which we present probe data.

exhibit a foliation marked by the elongation of white mica flakes. We did not investigate them more than under the microscope due to the lack of critical mineral assemblages and to the poor outcropping context.

\section{Methods, Mineral Chemistry, and Age Determination}

To determine the PT conditions of formation of the metamorphic sole using pseudosection modeling, we needed first to study the samples under the microscope. We then collected chemical data for each mineral (mainly clinopyroxene, amphibole, and feldspar). We present below a compilation of our petrological study that is also summarized on Figure 4. We then summarize the chemical data obtained for the investigated samples.

\subsection{Methods}

Microprobe analyses were performed with Cameca SXFive, SX 100, and a JEOL electron probe microanalyzer at CAMPARIS (Sorbonne Université, Paris) and GeoLab (Utrecht University), respectively. In all cases, we adopted classical analytical conditions (15-kV acceleration voltage, $10-\mathrm{nA}$ beam current, and 3- $\mu \mathrm{m}$ beam size; wavelength-dispersive spectroscopy mode). For calibration, we used diopside ( $\mathrm{Ca}, \mathrm{Mg}$, and $\mathrm{Si}$ ), orthoclase ( $\mathrm{K}$ and $\mathrm{Al}), \mathrm{FeO}(\mathrm{Fe})$, albite $(\mathrm{Na}), \mathrm{Cr}_{2} \mathrm{O}_{3}(\mathrm{Cr})$, and $\mathrm{MnTiO}_{3}(\mathrm{Mn}$, and $\mathrm{Ti})$ in Paris and Albite ( $\mathrm{Si}$ and $\mathrm{Al})$, Jadeite (Na), TiO (Ti), Adularia (K), Diopside (Ca), Forsterite (Mg), Hematite (Fe), Tephroite (Mn), and $\mathrm{Cr}_{2} \mathrm{O}_{3}(\mathrm{Cr})$ in Utrecht.

Whole rock compositions (major and trace elements) were obtained for five samples. All samples were analyzed at Actlabs (Canada) using their standard procedures (available online at https://actlabs.com/geochemistry/lithogeochemistry-and-whole-rock-analysis/lithogeochemistry/; last accessed on 13 December 2019).

We selected two amphibole-bearing samples for Ar/Ar determination. The two samples were crushed and sieved to obtain 180-250- $\mu \mathrm{m}$ fractions. The finer particles were decanted off in tap water, and the coarser residue further ultrasonically washed in acetone and deionized water several times. The optically best grains, void of any coatings, were handpicked under a stereomicroscope. The samples were packed in aluminum capsules together with the Taylor Creek Rhyolite flux monitor standard along with zero age reagent grade $\mathrm{K}_{2} \mathrm{SO}_{4}$ and optical grade $\mathrm{CaF}_{2}$ salts for interference corrections. The samples were irradiated at 

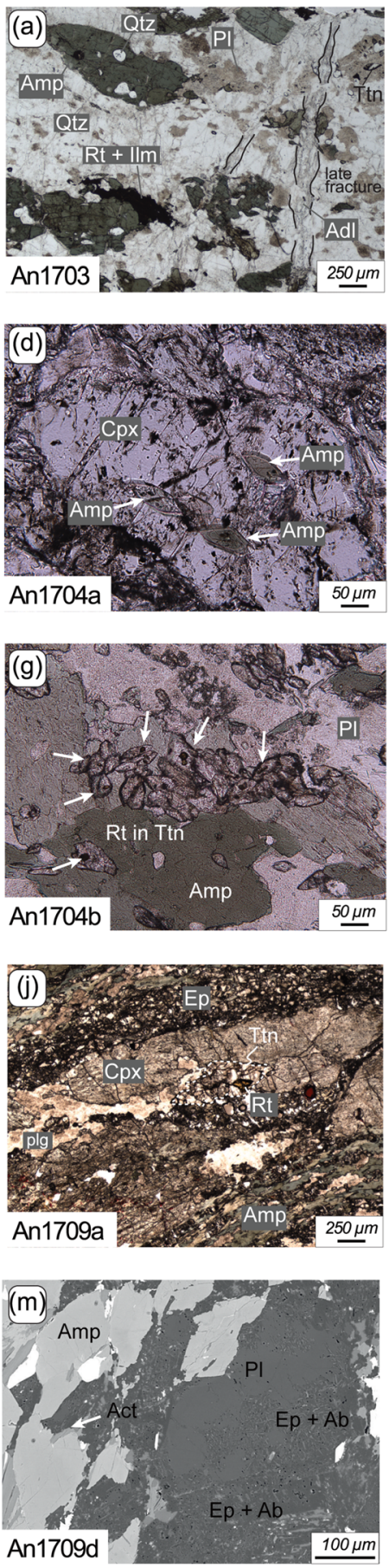
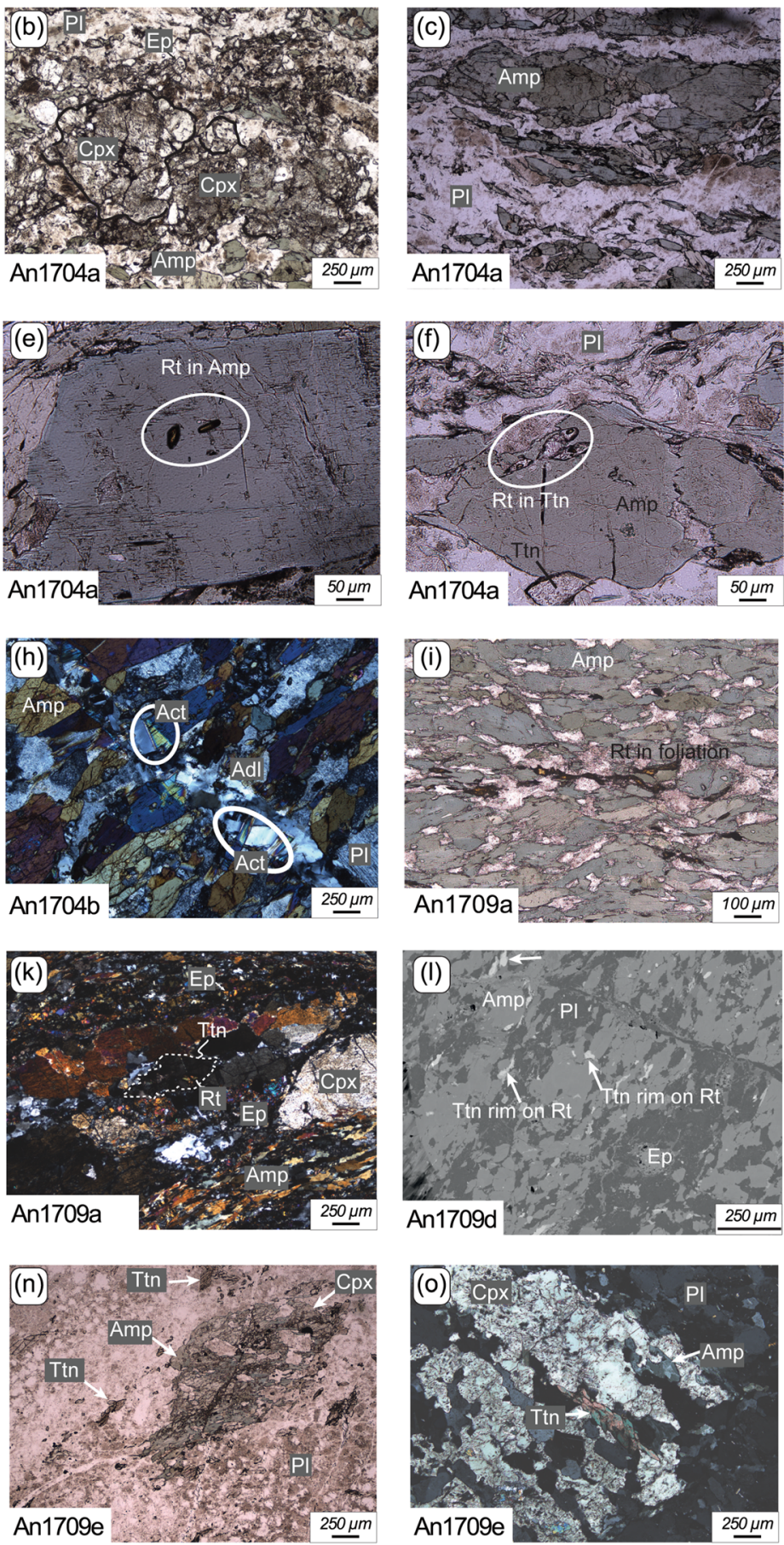

Figure 3. Microphotographs of representative sole samples. All mineral abbreviations are after Whitney and Evans (2010). (a) Plain polarized light (PPL) view of a quartz-rich sample. Late fracture is filled with adularia. (b) PPL picture showing the initial clinopyroxene still preserved in sample AN1704a. (c) PPL view of the matrix made of amphibole and plagioclase. (d) Close up on a clinopyroxene with amphibole inclusions. (e) Close up on an amphibole with inclusion of rutile and (f) inclusion of rutile in titanite at the edge of an amphibole. (g) Rutile inclusion in titanite. (h) Cross-polarized picture of late fillings of adularia with overgrowing actinolite on high-temperature amphibole. (i) General PPL view of sample AN1709a depicting the main foliation and rutile and ilmenite coexisting with amphibole and plagioclase. ( $\mathrm{j}, \mathrm{k}$ ) PPL and XPL views of the preserved clinopyroxene in sample AN1709a. Note the big rutile included in titanite (1) backscattered picture of sample AN1709d showing the general texture. Arrows indicate titanite rim over rutile. (m) Close-up view of a plagioclase with needles of epidote growing in places. (n, o) PPL and XPL views of sample AN1709e showing clinopyroxene and green amphibole overgrowth. 

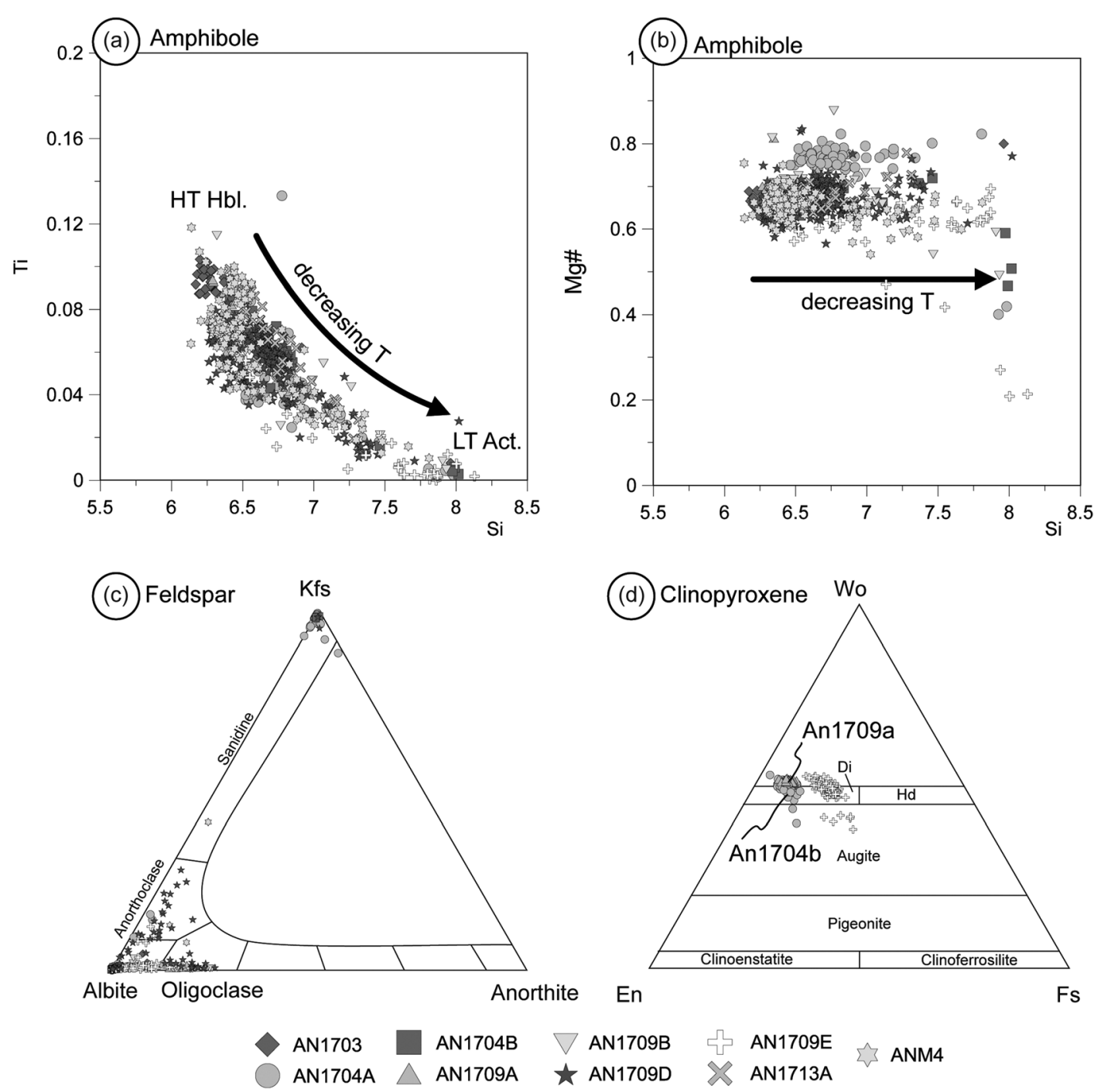

Figure 4. Chemical composition of minerals from the metamorphic sole. (a) Amphibole: Ti a.p.f.u versus Si a.p.f.u. (b) Amphibole: $\mathrm{Mg} \#$ versus Si a.p.f.u. with $\mathrm{Mg} \#=\mathrm{Mg} /\left(\mathrm{Mg}+\mathrm{Fe}^{2+}\right)$. (c) Ternary representation of the feldspar. Analysis close to the $\mathrm{K}$ feldspar pole corresponds to adularia in late vein. (d) Ternary representation of clinopyroxene. Mineral abbreviations are after Whitney and Evans (2010).

Institutt for Energiteknikk, Kjeller, Norway, for approximately $88.5 \mathrm{hr}$, with a nominal neutron flux density of approximately $1.3 \times 10^{13} \mathrm{n} \times\left(\mathrm{cm}^{-2} \mathrm{~s}^{-1}\right)$. The interference correction factors for the production of isotopes from $\mathrm{Ca}$ and $\mathrm{K}$ are available in the online appendix (Plunder et al., 2020). Samples were placed in a 3.5-mm pit size aluminum sample disk and step heated using a defocused 3.5- $\mathrm{mm} \mathrm{CO}_{2}$ laser beam from Photon Machine Fusions 10.6 with a flat energy spectrum. The extracted gases from the sample cell were expanded into a piston-free Stirling cryocooler, held at $-130{ }^{\circ} \mathrm{C}$, for trapping potential water vapor and further into a two-stage low volume extraction line (approximately $300 \mathrm{~cm}^{3}$ ), both stages equipped with SAES GP-50 (st101 alloy) getters, the first running hot (approximately $350^{\circ} \mathrm{C}$ ) and the second running cold. The gas was analyzed with a MAP 215-50 mass spectrometer in static mode, installed at the Geological Survey of Norway. The peaks and baseline (AMU = 36.2) were determined during peak hopping for 10 cycles (15 integrations per cycle and 30 integrations on mass $\left.{ }^{36} \mathrm{Ar}\right)$ on the different masses $\left({ }^{41-35} \mathrm{AMU}\right)$ on a Balzers SEV 217 electron multiplier in analog mode and regressed back to zero inlet time. Blanks were analyzed every third measurement. After blank correction, a correction for mass fractionation, ${ }^{37} \mathrm{Ar}$ and ${ }^{39} \mathrm{Ar}$ decay, and neutron-induced interference reactions produced in the reactor were undertaken using in-house software AgeMonster, written by M. Ganerød. It implements the equations of McDougall and Harrison (1999) and 
the newly proposed decay constant for ${ }^{40} \mathrm{~K}$ after Renne et al. (2010). $\mathrm{A}{ }^{40} \mathrm{Ar} /{ }^{36} \mathrm{Ar}$ ratio of $298.56 \pm 0.31$ from Lee et al. (2006) was used for the atmospheric argon correction and mass discrimination calculation using a power law distribution of the masses. We calculated $J$ values relative to an age of $28.619 \pm 0.036$ Ma for the Taylor Creek Rhyolite sanidine flux monitor (Renne et al., 2010). We define a plateau according to the following requirements: at least three consecutive steps overlapping at the 95\% confidence level (1.96 $\sigma$ ) using the strict test: overlap if: $\operatorname{abs}\left(\operatorname{age}_{n}-\right.$ age $\left._{n+1}\right)<1.96 \sqrt{\left(\sigma_{n}^{2}+\sigma_{n+1}^{2}\right)}$ (if errors quoted at $\left.1 \sigma\right), \geq 50 \%$ cumulative ${ }^{39} \mathrm{Ar}$ released, and mean square of weighted deviates less than the two-tailed Student $T$ critical test statistics for $n-1$. Weighted mean ages are calculated by weighting on the inverse of the analytical variance. The uncertainties are expanded in cases where mean square of weighted deviates $>1$ using $\sigma^{*} \sqrt{M S W D}$ to account for this excess error contribution.

\subsection{Mineral Chemistry}

The composition of the minerals that we observed in thin sections reported below and representative analysis are given in Table 2. The full data set is published online (Plunder et al., 2020).

\subsubsection{Amphibole}

The composition of the amphibole crystals defining the main fabric is generally calcic between magnesioand tschermakitic-hornblende following the classification of Leake et al. (1997). The late overgrowth plots in the actinolite field and some intermediate composition were also found (Figures $4 \mathrm{a}$ and $4 \mathrm{~b}$ ). The Si content per formula unit (a.p.f.u.) varies between 6 and 8 (hornblende and actinolite, respectively). The XMg (with $\mathrm{XMg}=\mathrm{Mg} /\left[\mathrm{Mg}+\mathrm{Fe}^{2+}\right]$ ) is generally between 0.6 to 0.8 . The analysis of a Ti versus Si diagram shows a decreasing trend with relation to the textural site of the amphibole. The Ti a.p.fu. content varies between 0.12 in hornblende to 0 in actinolite and $[\mathrm{Na}+\mathrm{K}]^{\mathrm{A}}$ varies from 0.6 to 0 .

\subsubsection{Clinopyroxene}

Clinopyroxene has a diopside composition and shows differences in between samples (Figure 4d). The average $\mathrm{XMg}$ (with $\mathrm{XMg}=\mathrm{Mg} /\left[\mathrm{Mg}+\mathrm{Fe}^{2+}\right]$ ) is 0.80 for sample AN1709a, 0.64 for sample AN1709e, and 0.84 for sample AN1704a. The Na a.p.f.u. is on average 0.04 for samples AN1704a and AN1709a and 0.07 for sample AN1709e. We observed small intrasample variation in the order of \pm 0.02 to \pm 0.04 for the XMg and of \pm 0.02 to $\pm 0.04 \mathrm{Na}$ a.p.f.u. (Table 2).

\subsubsection{Feldspar}

All the primary feldspars are plagioclase (Figure 4c). They have a composition ranging from Xanorthite $=0$ to Xanorthite $=20$ plotting in the field of albite to oligoclase. The late feldspar are classified as potassic feldspar, being identified as adularia with a formula unit very close to the endmember $\left(\mathrm{KAlSi}_{3} \mathrm{O}_{8}\right.$; Figure $\left.3 \mathrm{c}\right)$, a common mineral developing during episodes of hydrothermalism/fluid circulation at shallow levels (Cerny \& Chapman, 1986).

\subsubsection{Ti-bearing phases}

When measured, rutile or ilmenite show composition close to the pure end-members with formula unit close to $\mathrm{TiO}_{2}$ and $\mathrm{FeTiO}_{3}$.

\subsection{Ar/Ar Ages}

The main results and the degassing spectra can be found in Table 3 and Figure 5, respectively. The raw analytical mass spectrometer output (following data reporting norms of Renne et al., 2010) is given in the online data set (Plunder et al., 2020). The step heating experiments of amphiboles from samples AN1704A and AN1709A (Figures 5a and 5b) reveal overlapping step ages of parts of the spectrum, defining inverse variance weighted plateau ages of $106.4 \pm 2.1$ and $105.3 \pm 1.6 \mathrm{Ma}$, respectively. These ages are within error of each other (Table 3). We interpret the plateau dates as reliable estimators of the cooling age of the metamorphic sole below $\sim 450-550{ }^{\circ} \mathrm{C}$ (i.e., the closure temperature of the Ar/Ar system in hornblende; Baldwin et al., 1990; Harrison, 1982).

\section{Thermobarometry}

\subsection{Amphibole Plagioclase Thermometry and Barometry}

We determined the crystallization temperature of hornblende and plagioclase pairs using the empirical thermometer of Holland and Blundy (1994). Since the plagioclase is often destabilized in our samples, we only took the analyses with xanorthite $>0.10$ and a clear textural equilibrium relation with the amphibole 
Table 2

Selection of Representative Analysis for Amphibole, Clinopyroxene, and Feldspar

\begin{tabular}{|c|c|c|c|c|c|c|c|c|c|c|}
\hline Sample & AN1703 & AN1703 & AN1704A & AN1704A & AN1704A & AN1704A & AN1704B & AN1704B & AN1704B & AN1709A \\
\hline Analog \# & 7 & 12 & 18 & 19 & 2 & 3 & 4 & 7 & 8 & 14 \\
\hline $\mathrm{SiO}_{2}$ & 42.49 & 42.11 & 47.19 & 48.52 & 52.74 & 52.41 & 53.46 & 45.20 & 43.42 & 42.97 \\
\hline $\mathrm{TiO}_{2}$ & 0.82 & 0.87 & 0.47 & 0.39 & 0.02 & 0.04 & 0.03 & 0.58 & 0.69 & 0.79 \\
\hline $\mathrm{Al}_{2} \mathrm{O}_{3}$ & 12.94 & 13.18 & 10.39 & 9.54 & 0.16 & 0.07 & 0.14 & 10.25 & 11.92 & 12.31 \\
\hline $\mathrm{Cr}_{2} \mathrm{O}_{3}$ & 0.03 & 0.04 & 0.12 & 0.10 & 0.05 & 0.00 & 0.00 & 0.00 & 0.02 & 0.04 \\
\hline $\mathrm{FeO}$ & 16.62 & 17.02 & 11.61 & 12.01 & 22.54 & 23.90 & 19.08 & 14.51 & 14.82 & 14.69 \\
\hline $\mathrm{MnO}$ & 0.68 & 0.68 & 0.34 & 0.37 & 0.48 & 0.82 & 0.59 & 0.43 & 0.42 & 0.23 \\
\hline $\mathrm{MgO}$ & 10.23 & 10.10 & 14.07 & 14.32 & 9.12 & 8.57 & 11.02 & 11.99 & 11.17 & 11.49 \\
\hline $\mathrm{CaO}$ & 11.10 & 10.99 & 12.42 & 12.56 & 12.19 & 12.19 & 12.18 & 11.82 & 11.61 & 11.14 \\
\hline $\mathrm{Na}_{2} \mathrm{O}$ & 1.91 & 1.97 & 1.18 & 1.01 & 0.21 & 0.13 & 0.20 & 1.38 & 1.61 & 2.05 \\
\hline $\mathrm{K}_{2} \mathrm{O}$ & 0.63 & 0.67 & 0.62 & 0.52 & 0.03 & 0.06 & 0.06 & 0.53 & 0.60 & 0.60 \\
\hline Total & 97.45 & 97.63 & 98.41 & 99.34 & 97.55 & 98.20 & 96.75 & 96.68 & 96.29 & 96.30 \\
\hline \multicolumn{11}{|c|}{ Formula unit } \\
\hline $\mathrm{Si}$ & 6.27 & 6.21 & 6.75 & 6.87 & 7.98 & 7.92 & 8.02 & 6.67 & 6.46 & 6.37 \\
\hline $\mathrm{Al}$ iv & 1.73 & 1.79 & 1.25 & 1.13 & 0.02 & 0.01 & 0.00 & 1.33 & 1.54 & 1.63 \\
\hline $\mathrm{Al}$ vi & 0.52 & 0.50 & 0.50 & 0.46 & 0.01 & 0.00 & 0.02 & 0.45 & 0.55 & 0.52 \\
\hline $\mathrm{Ti}$ & 0.09 & 0.10 & 0.05 & 0.04 & 0.00 & 0.00 & 0.00 & 0.06 & 0.08 & 0.09 \\
\hline $\mathrm{Cr}$ & 0.00 & 0.00 & 0.01 & 0.01 & 0.01 & 0.00 & 0.00 & 0.00 & 0.00 & 0.00 \\
\hline $\mathrm{Fe}^{3}+$ & 0.85 & 0.94 & 0.38 & 0.40 & 0.00 & 0.13 & 0.00 & 0.52 & 0.56 & 0.69 \\
\hline $\mathrm{Fe}^{2}+$ & 1.20 & 1.16 & 1.01 & 1.03 & 2.85 & 2.89 & 2.39 & 1.28 & 1.28 & 1.13 \\
\hline Mn & 0.09 & 0.08 & 0.04 & 0.04 & 0.06 & 0.11 & 0.08 & 0.05 & 0.05 & 0.03 \\
\hline $\mathrm{Mg}$ & 2.25 & 2.22 & 3.00 & 3.02 & 2.06 & 1.93 & 2.46 & 2.64 & 2.48 & 2.54 \\
\hline $\mathrm{Ca}$ & 1.75 & 1.74 & 1.90 & 1.91 & 1.98 & 1.97 & 1.96 & 1.87 & 1.85 & 1.77 \\
\hline $\mathrm{Na}$ & 0.55 & 0.56 & 0.33 & 0.28 & 0.06 & 0.04 & 0.06 & 0.39 & 0.47 & 0.59 \\
\hline $\mathrm{K}$ & 0.12 & 0.13 & 0.11 & 0.09 & 0.01 & 0.01 & 0.01 & 0.10 & 0.11 & 0.11 \\
\hline $\mathrm{OH}^{*}$ & 2.00 & 2.00 & 2.00 & 2.00 & 2.00 & 2.00 & 2.00 & 2.00 & 2.00 & 2.00 \\
\hline $\mathrm{XMg}$ & 0.65 & 0.66 & 0.75 & 0.75 & 0.42 & 0.40 & 0.51 & 0.67 & 0.66 & 0.69 \\
\hline $\mathrm{XFe}^{3}+$ & 0.62 & 0.65 & 0.43 & 0.46 & 0.04 & 0.03 & 0.00 & 0.53 & 0.51 & 0.57 \\
\hline \multicolumn{11}{|c|}{ Amphibole } \\
\hline Sample & AN1709A & AN1709B & & 709D & AN1709D & AN1709E & AN1709E & AN1709E & AN1713A & \\
\hline Analog \# & 3 & 23 & & & 57 & 4 & 5 & 6 & 20 & \\
\hline $\mathrm{SiO}_{2}$ & 42.74 & 43.95 & & & 52.60 & 53.23 & 50.60 & 46.59 & 44.82 & \\
\hline $\mathrm{TiO}_{2}$ & 0.64 & 0.63 & & & 0.08 & 0.00 & 0.19 & 0.17 & 0.63 & \\
\hline $\mathrm{Al}_{2} \mathrm{O}_{3}$ & 12.15 & 12.15 & & & 2.87 & 1.62 & 3.97 & 6.84 & 10.43 & \\
\hline $\mathrm{Cr}_{2} \mathrm{O}_{3}$ & 0.04 & 0.01 & & & 0.00 & 0.01 & 0.00 & 0.04 & 0.08 & \\
\hline $\mathrm{FeO}$ & 14.81 & 14.03 & & & 15.27 & 14.68 & 16.09 & 18.19 & 13.41 & \\
\hline $\mathrm{MnO}$ & 0.30 & 0.25 & & 21 & 0.38 & 1.72 & 1.04 & 1.12 & 0.25 & \\
\hline $\mathrm{MgO}$ & 11.43 & 11.52 & & 57 & 13.13 & 13.20 & 12.26 & 10.52 & 12.20 & \\
\hline $\mathrm{CaO}$ & 11.45 & 11.30 & & 33 & 12.22 & 12.77 & 12.11 & 11.92 & 11.46 & \\
\hline $\mathrm{Na}_{2} \mathrm{O}$ & 2.18 & 1.62 & & 83 & 0.42 & 0.20 & 0.65 & 1.12 & 1.73 & \\
\hline $\mathrm{K}_{2} \mathrm{O}$ & 0.58 & 0.30 & & 56 & 0.28 & 0.06 & 0.32 & 0.52 & 0.47 & \\
\hline Total & 96.32 & 95.76 & & .04 & 97.26 & 97.49 & 97.23 & 97.04 & 95.48 & \\
\hline \multicolumn{11}{|c|}{ Formula unit } \\
\hline $\mathrm{Si}$ & 6.37 & 6.50 & & 45 & 7.71 & 7.81 & 7.47 & 6.99 & 6.68 & \\
\hline $\mathrm{Al}$ iv & 1.63 & 1.50 & & 55 & 0.29 & 0.19 & 0.53 & 1.01 & 1.32 & \\
\hline $\mathrm{Al}$ vi & 0.50 & 0.62 & & 63 & 0.20 & 0.09 & 0.16 & 0.20 & 0.51 & \\
\hline $\mathrm{Ti}$ & 0.07 & 0.07 & & 08 & 0.01 & 0.00 & 0.02 & 0.02 & 0.07 & \\
\hline
\end{tabular}

(Continues) 
Table 2

(continued)

\begin{tabular}{|c|c|c|c|c|c|c|c|c|}
\hline \multicolumn{9}{|c|}{ Amphibole } \\
\hline Sample & AN1709A & AN1709B & AN1709D & AN1709D & AN1709E & AN1709E & AN1709E & AN1713A \\
\hline Analog \# & 3 & 23 & 12 & 57 & 4 & 5 & 6 & 20 \\
\hline $\mathrm{Cr}$ & 0.00 & 0.00 & 0.00 & 0.00 & 0.00 & 0.00 & 0.00 & 0.01 \\
\hline $\mathrm{Fe}^{3}+$ & 0.58 & 0.63 & 0.59 & 0.06 & 0.00 & 0.25 & 0.51 & 0.42 \\
\hline $\mathrm{Fe}^{2}+$ & 1.26 & 1.10 & 1.15 & 1.81 & 1.80 & 1.74 & 1.77 & 1.26 \\
\hline $\mathrm{Mn}$ & 0.04 & 0.03 & 0.03 & 0.05 & 0.21 & 0.13 & 0.14 & 0.03 \\
\hline $\mathrm{Mg}$ & 2.54 & 2.54 & 2.53 & 2.87 & 2.89 & 2.70 & 2.35 & 2.71 \\
\hline $\mathrm{Ca}$ & 1.83 & 1.79 & 1.78 & 1.92 & 2.01 & 1.92 & 1.92 & 1.83 \\
\hline $\mathrm{Na}$ & 0.63 & 0.46 & 0.52 & 0.12 & 0.06 & 0.19 & 0.33 & 0.50 \\
\hline $\mathrm{K}$ & 0.11 & 0.06 & 0.10 & 0.05 & 0.01 & 0.06 & 0.10 & 0.09 \\
\hline $\mathrm{OH}^{*}$ & 2.00 & 2.00 & 2.00 & 2.00 & 2.00 & 2.00 & 2.00 & 2.00 \\
\hline $\mathrm{XMg}$ & 0.67 & 0.70 & 0.69 & 0.61 & 0.62 & 0.61 & 0.57 & 0.68 \\
\hline $\mathrm{XFe}^{3}+$ & 0.54 & 0.50 & 0.48 & 0.23 & 0.04 & 0.60 & 0.72 & 0.45 \\
\hline
\end{tabular}

\begin{tabular}{|c|c|c|c|c|c|c|c|c|}
\hline Sample & AN1709D & AN1704A & & AN1704A & AN1709A & AN1709A & & \\
\hline Analog \# & 3 & 67 & & 68 & 1 & 2 & & \\
\hline $\mathrm{SiO}_{2}$ & 68.48 & 65.71 & & 65.43 & 62.37 & 61.80 & & \\
\hline $\mathrm{TiO}_{2}$ & 0.03 & 0.06 & & 0.01 & 0.01 & 0.00 & & \\
\hline $\mathrm{Al}_{2} \mathrm{O}_{3}$ & 20.61 & 18.91 & & 18.89 & 22.67 & 23.04 & & \\
\hline $\mathrm{Cr}_{2} \mathrm{O}_{3}$ & 0.00 & 0.00 & & 0.00 & 0.00 & 0.00 & & \\
\hline $\mathrm{FeO}$ & 0.02 & 0.04 & & 0.08 & 0.19 & 0.08 & & \\
\hline $\mathrm{MnO}$ & 0.02 & 0.01 & & 0.06 & 0.00 & 0.03 & & \\
\hline $\mathrm{MgO}$ & 0.00 & 0.00 & & 0.00 & 0.00 & 0.01 & & \\
\hline $\mathrm{CaO}$ & 0.04 & 0.03 & & 0.03 & 4.06 & 4.45 & & \\
\hline $\mathrm{Na}_{2} \mathrm{O}$ & 12.51 & 0.12 & & 0.16 & 9.86 & 9.63 & & \\
\hline $\mathrm{K}_{2} \mathrm{O}$ & 0.04 & 15.94 & & 16.10 & 0.10 & 0.10 & & \\
\hline Total & 101.75 & 100.82 & & 100.76 & 99.26 & 99.13 & & \\
\hline $\mathrm{O \#}$ & 8 & 8 & & 8 & 8 & 8 & & \\
\hline $\mathrm{Si}$ & 2.95 & 3.00 & & 2.99 & 2.79 & 2.77 & & \\
\hline $\mathrm{Al}$ & 1.05 & 1.02 & & 1.02 & 1.19 & 1.22 & & \\
\hline $\mathrm{Ti}$ & 0.00 & 0.00 & & 0.00 & 0.00 & 0.00 & & \\
\hline $\mathrm{Fe}$ & 0.00 & 0.00 & & 0.00 & 0.01 & 0.00 & & \\
\hline $\mathrm{Mn}$ & 0.00 & 0.00 & & 0.00 & 0.00 & 0.00 & & \\
\hline $\mathrm{Mg}$ & 0.00 & 0.00 & & 0.00 & 0.00 & 0.00 & & \\
\hline $\mathrm{Ca}$ & 0.00 & 0.00 & & 0.00 & 0.19 & 0.21 & & \\
\hline $\mathrm{Na}$ & 1.05 & 0.01 & & 0.01 & 0.85 & 0.84 & & \\
\hline $\mathrm{K}$ & 0.00 & 0.93 & & 0.94 & 0.01 & 0.01 & & \\
\hline Or & 0.18 & 98.71 & & 98.36 & 0.53 & 0.54 & & \\
\hline $\mathrm{Ab}$ & 99.65 & 1.13 & & 1.49 & 81.03 & 79.24 & & \\
\hline An & 0.16 & 0.17 & & 0.16 & 18.44 & 20.22 & & \\
\hline \multicolumn{9}{|c|}{ Clinopyroxene } \\
\hline Sample & AN1709a & AN1709a & AN1709a & AN1709a & AN1704A & AN1704A & AN1709E & AN1709E \\
\hline Analog \# & 1 & 2 & 3 & 4 & 1 & 2 & 1 & 2 \\
\hline $\mathrm{SiO}_{2}$ & 53.76 & 54.26 & 53.59 & 53.37 & 53.76 & 54.26 & 52.65 & 52.11 \\
\hline $\mathrm{TiO}_{2}$ & 0.03 & 0.08 & 0.01 & 0.10 & 0.03 & 0.08 & 0.03 & 0.02 \\
\hline $\mathrm{Al}_{2} \mathrm{O}_{3}$ & 1.32 & 1.45 & 1.42 & 1.93 & 1.32 & 1.45 & 0.54 & 0.65 \\
\hline $\mathrm{Cr}_{2} \mathrm{O}_{3}$ & 0.06 & 0.00 & 0.03 & 0.04 & 0.06 & 0.00 & 0.03 & 0.00 \\
\hline $\mathrm{FeO}$ & 5.74 & 5.89 & 5.51 & 6.38 & 5.74 & 5.89 & 10.61 & 11.20 \\
\hline $\mathrm{MnO}$ & 0.57 & 0.68 & 0.71 & 0.56 & 0.57 & 0.68 & 1.40 & 1.24 \\
\hline
\end{tabular}


Table 2

(continued)

\begin{tabular}{|c|c|c|c|c|c|c|c|c|}
\hline \multicolumn{9}{|c|}{ Clinopyroxene } \\
\hline Sample & AN1709a & AN1709a & AN1709a & AN1709a & AN1704A & AN1704A & AN1709E & AN1709E \\
\hline Analog \# & 1 & 2 & 3 & 4 & 1 & 2 & 1 & 2 \\
\hline $\mathrm{MgO}$ & 14.47 & 14.48 & 14.74 & 14.28 & 14.47 & 14.48 & 11.12 & 10.84 \\
\hline $\mathrm{CaO}$ & 24.41 & 24.23 & 24.08 & 24.39 & 24.41 & 24.23 & 23.22 & 22.77 \\
\hline $\mathrm{Na}_{2} \mathrm{O}$ & 0.57 & 0.60 & 0.49 & 0.65 & 0.57 & 0.60 & 0.58 & 0.91 \\
\hline $\mathrm{K}_{2} \mathrm{O}$ & 0.01 & 0.01 & 0.04 & 0.03 & 0.01 & 0.01 & 0.04 & 0.01 \\
\hline Total & 100.93 & 101.68 & 100.63 & 101.74 & 100.93 & 101.68 & 100.24 & 99.74 \\
\hline \multicolumn{9}{|c|}{ Formula unit } \\
\hline $\mathrm{O} \#$ & 6 & 6 & 6 & 6 & 6 & 6 & 6 & 6 \\
\hline $\mathrm{Si}$ & 1.96 & 1.97 & 1.96 & 1.94 & 1.96 & 1.97 & 1.99 & 1.97 \\
\hline $\mathrm{Ti}$ & 0.00 & 0.00 & 0.00 & 0.00 & 0.00 & 0.00 & 0.00 & 0.00 \\
\hline $\mathrm{Al}$ & 0.06 & 0.06 & 0.06 & 0.08 & 0.06 & 0.06 & 0.02 & 0.03 \\
\hline $\mathrm{Cr}$ & 0.00 & 0.00 & 0.00 & 0.00 & 0.00 & 0.00 & 0.00 & 0.00 \\
\hline $\mathrm{Fe}^{3}+$ & 0.05 & 0.04 & 0.05 & 0.09 & 0.05 & 0.04 & 0.05 & 0.09 \\
\hline $\mathrm{Fe}^{2}+$ & 0.12 & 0.14 & 0.12 & 0.11 & 0.12 & 0.14 & 0.29 & 0.26 \\
\hline $\mathrm{Mn}$ & 0.02 & 0.02 & 0.02 & 0.02 & 0.02 & 0.02 & 0.04 & 0.04 \\
\hline $\mathrm{Mg}$ & 0.79 & 0.78 & 0.80 & 0.77 & 0.79 & 0.78 & 0.63 & 0.61 \\
\hline $\mathrm{Ca}$ & 0.96 & 0.94 & 0.94 & 0.95 & 0.96 & 0.94 & 0.94 & 0.92 \\
\hline $\mathrm{Na}$ & 0.04 & 0.04 & 0.04 & 0.05 & 0.04 & 0.04 & 0.04 & 0.07 \\
\hline $\mathrm{K}$ & 0.00 & 0.00 & 0.00 & 0.00 & 0.00 & 0.00 & 0.00 & 0.00 \\
\hline $\mathrm{XMg}$ & 0.87 & 0.85 & 0.87 & 0.88 & 0.87 & 0.85 & 0.68 & 0.70 \\
\hline En & 0.42 & 0.42 & 0.43 & 0.42 & 0.42 & 0.42 & 0.34 & 0.34 \\
\hline Fs & 0.07 & 0.07 & 0.06 & 0.06 & 0.07 & 0.07 & 0.16 & 0.15 \\
\hline Wo & 0.51 & 0.51 & 0.51 & 0.52 & 0.51 & 0.51 & 0.51 & 0.51 \\
\hline
\end{tabular}

(e.g., pairs we measured together at the microprobe). For amphibole, we used the highest Ti content we measured ( 0.06 to $0.08 \mathrm{Ti}$ a.p.f.u; Figure $4 \mathrm{a}$ ) as it is interpreted to increase with temperature (Ernst \& Liu, 1998). When performing the thermometry, we first set the pressure to $0.8 \mathrm{GPa}$. This is a rather conservative assumption since the reaction is almost entirely dependent on temperature. We then calculated the pressure using the calcic amphibole barometer of Molina et al. (2015). We retrieved pressure between 0.6 and $0.9 \mathrm{GPa}$ (Figure 6a). Using the calculated pressure, we used an iterative scheme to refine the temperature. We obtained temperatures between $600{ }^{\circ} \mathrm{C}$ and $690{ }^{\circ} \mathrm{C}$ from the following equation, edenite +4 quartz $=$ tremolite + albite, and between $630{ }^{\circ} \mathrm{C}$ and $680{ }^{\circ} \mathrm{C}$ from the equation edenite + albite $=$ richterite + anorthite, with pressure range between 0.6 and $0.9 \mathrm{GPa}$ (Figure 6a). The difference with imposed pressure stays within approximately $60{ }^{\circ} \mathrm{C}$, and our results are coherent with previous estimates for similar paragenesis (Soret et al., 2017).

Table 3

Ar/Ar Data

\begin{tabular}{|c|c|c|c|c|c|c|c|c|c|c|c|}
\hline \multirow[b]{2}{*}{ Sample } & \multirow[b]{2}{*}{ Material } & \multirow[b]{2}{*}{$\begin{array}{l}\text { Steps } \\
(n)\end{array}$} & \multicolumn{5}{|c|}{ Spectrum } & \multicolumn{4}{|c|}{ Inverse isochron } \\
\hline & & & ${ }^{39} \mathrm{Ar}$ & Age $\pm 1.96 \mathrm{~s}$ & $\begin{array}{l}\text { MSWD } \\
\text { (P) }\end{array}$ & $\mathrm{TGA} \pm 1.96 \mathrm{~s}$ & $\begin{array}{c}\mathrm{K} / \\
\mathrm{Ca} \pm 1.96 \mathrm{~s}\end{array}$ & Age $\pm 1.96 \mathrm{~s}$ & $\begin{array}{l}\text { MSWD } \\
\text { (P) }\end{array}$ & $\begin{array}{c}\text { Trapped } \\
{ }^{40} \mathrm{Ar} /{ }^{36} \mathrm{Ar}\end{array}$ & $\begin{array}{c}\text { Spread } \\
(\%)\end{array}$ \\
\hline AN1704A & Amphibole & $\begin{array}{c}13- \\
16(4)\end{array}$ & 73.1 & $106.38 \pm 2.18$ & $\begin{array}{c}1.21 \\
(0.31)\end{array}$ & $106.58 \pm 2.17$ & $0.07 \pm 0.001$ & $107.73 \pm 6.29$ & $\begin{array}{l}1.68 \\
(0.19)\end{array}$ & $293.01 \pm 24.53$ & 33.9 \\
\hline AN1709A & Amphibole & $\begin{array}{c}18- \\
22(5)\end{array}$ & 46.33 & $106.06 \pm 1.27$ & $\begin{array}{c}1.09 \\
(0.36)\end{array}$ & $108.61 \pm 1.58$ & $0.12 \pm 0.001$ & $104.75 \pm 1.96$ & $\begin{array}{c}0.54 \\
(0.65)\end{array}$ & $306.27 \pm 9.29$ & 38 \\
\hline
\end{tabular}

Note. $n$, number of steps taken for age calculation.

Bold number emphasis the retained ages. 


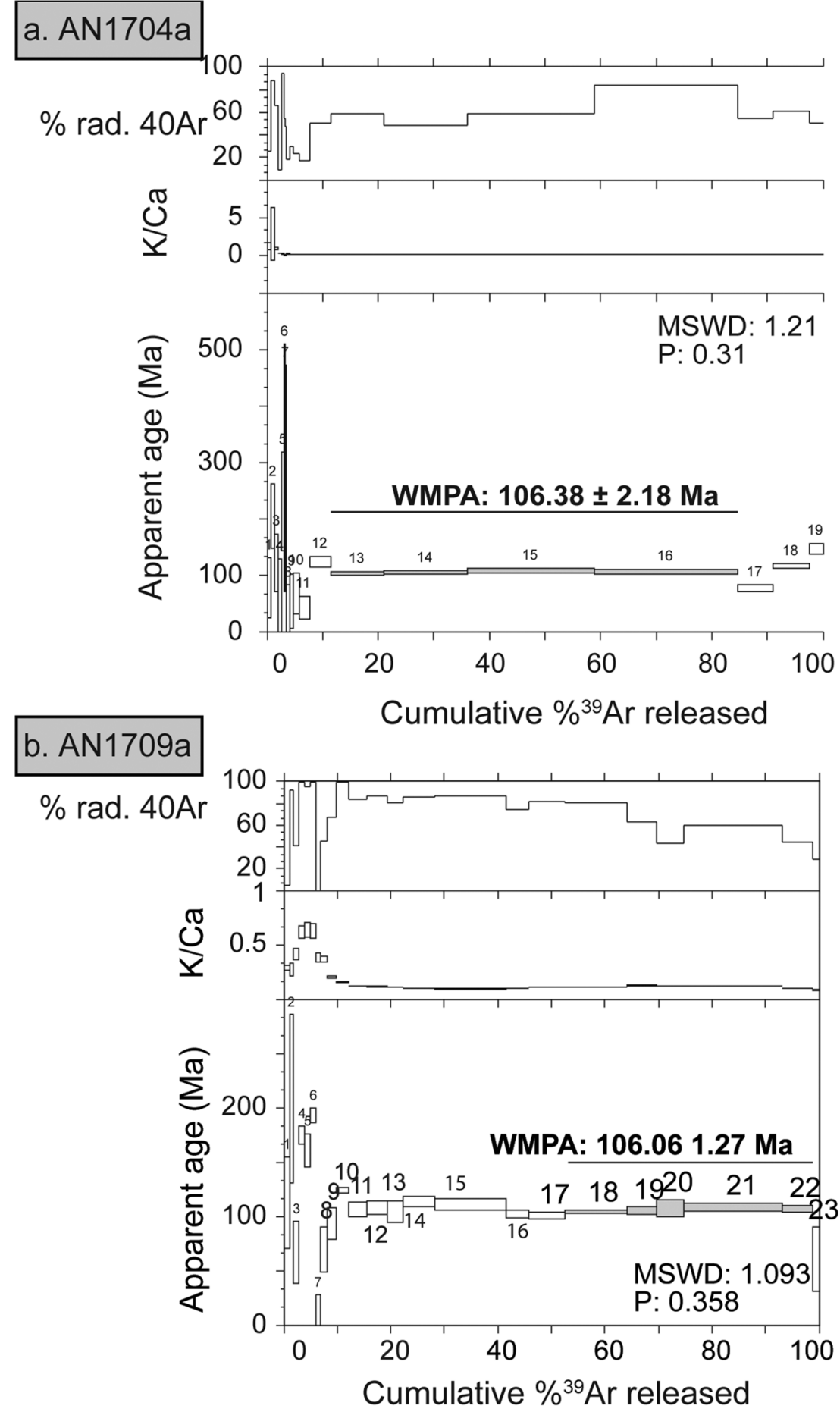

Figure 5. Degassing spectra for samples (a) AN1704a and (b) AN1709a. Steps 16 and 17 are omitted in the age calculation. Terms MSWD, P, and WMPA denote mean squared weighted deviance, probability of fit, and weighted mean plateau age, respectively. The $\mathrm{K} / \mathrm{Ca}$ ration is calculated as ${ }^{39} \mathrm{Ar} /{ }^{37} \mathrm{Ar}$.

\subsection{Pseudosection Modeling}

One problem of pseudosection modeling with high variance rocks is to evaluate the amount of water and the degree of oxidation of the rock. We calculated different pseudosection (i.e., a phase diagram for a fixed bulk composition) using an updated version of the THERIAK-DOMINO software package (de Capitani \& Brown, 1987; de Capitani \& Petrakakis, 2010; Jørgensen et al., 2019; available on D. Tinkham's website 
(a)

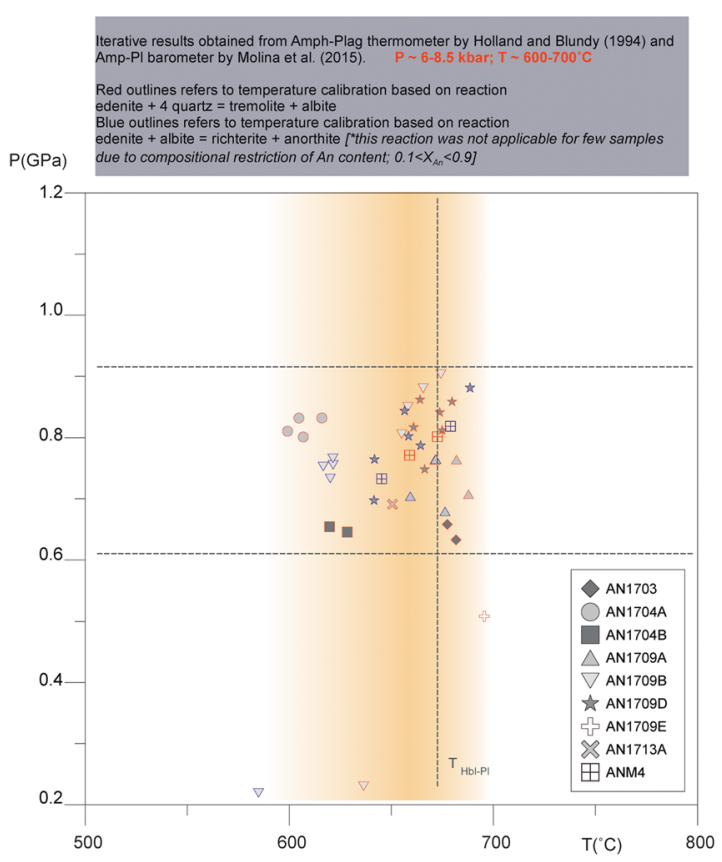

(c)

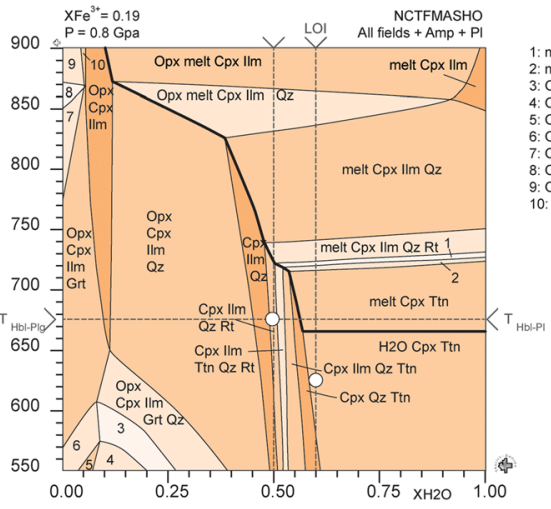
1: melt $C p x \| l m Q z R t T t n$
2. melt $C p x \| m Q z T t n$
3: Opx $C p x \operatorname{lm} Q \mathbf{t r} Q z R t$ 4: $\mathrm{Opx} \mathrm{Cpx} \mathrm{Grt} \mathrm{Qz} \mathrm{Rt}$
5: $\mathrm{Opx} \mathrm{Cpx} \mathrm{Grt} \mathrm{Rt}$ 6: Opx Cpx IIm Grt Rt 3: Opx Cpx grt ilm OI $\mathrm{Sp}$ 9: Opx Cpx IIm OI Sp

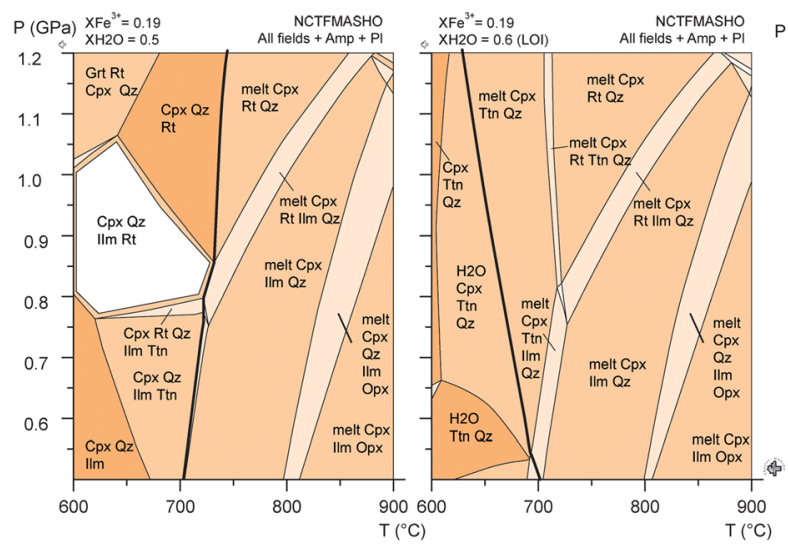

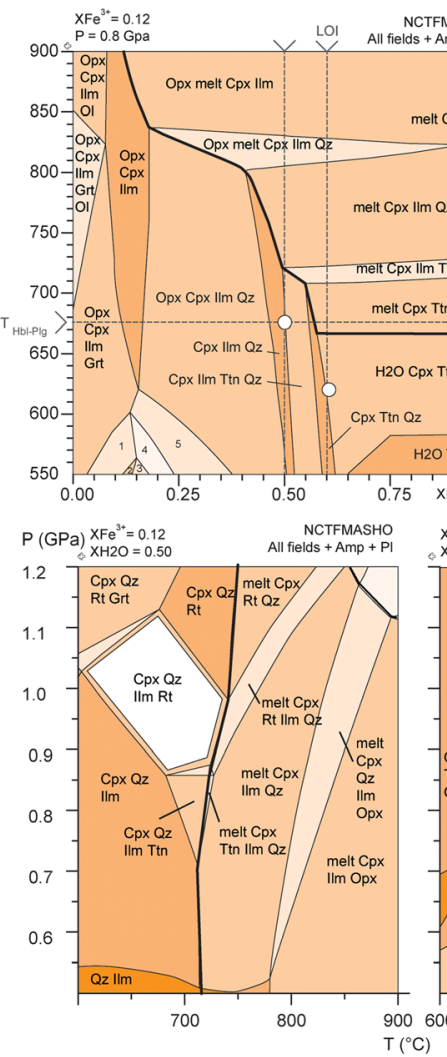

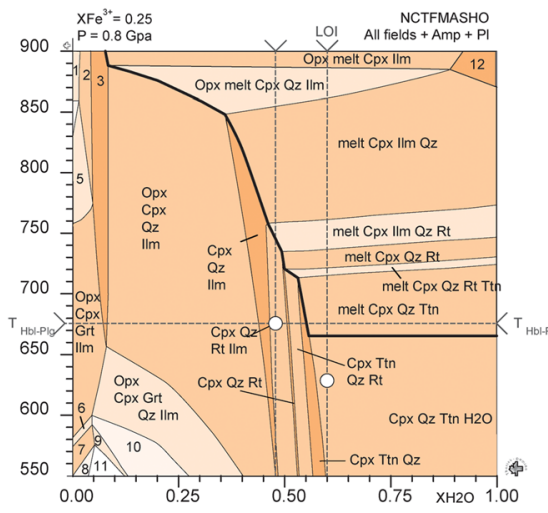

(b)

1: $\mathrm{Cpx} C p x \lim G r t R t$
2: Opx Cpx Grt Rt
3. $\mathrm{Opx}$ Cpx Grt Rt

3: Opx Cpx Grt Rt Qz

5: $\mathrm{Opx} \mathrm{Cpx} \lim \mathrm{Grt} \mathrm{Oz}$

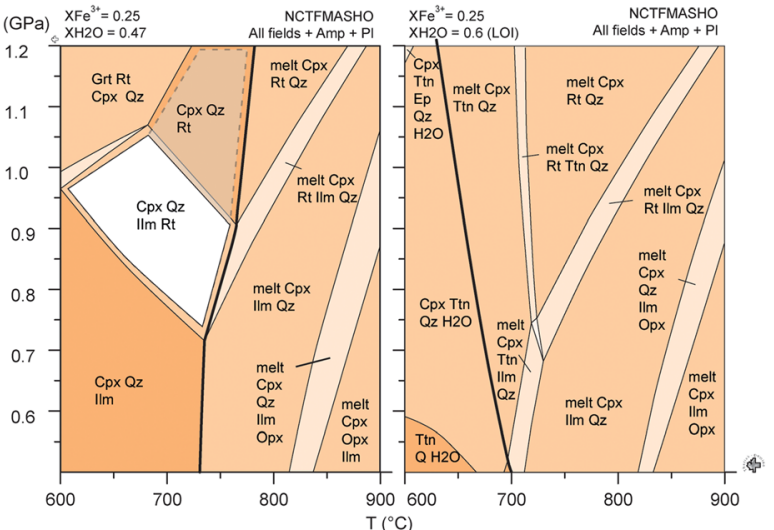

Figure 6. (a) Results of the hornblende-plagioclase empirical thermobarometry. (b) Temperature versus $\mathrm{XH}_{2} \mathrm{O}$ pseudosection with $\mathrm{XFe}^{3+}=0.12$. PT pseudosection for different amounts of water. (c) Temperature versus $\mathrm{XH}_{2} \mathrm{O}$ pseudosection with $\mathrm{XFe}^{3+}=0.19$. PT pseudosection for different amounts of water. (d) Temperature versus $\mathrm{XH}_{2} \mathrm{O}$ pseudosection with $\mathrm{XFe}^{3+}=0.25$. PT pseudosection for different amounts of water. 
Table 4

Bulk Composition (mol \%) for Sample AN1709a Used for Pseudosection Modeling. The Table Reports all Bulk Used for Figure 6

\begin{tabular}{|c|c|c|c|c|c|c|c|c|c|c|c|}
\hline AN1709a & $\mathrm{H}$ & $\mathrm{Si}$ & $\mathrm{Al}$ & $\mathrm{Ca}$ & $\mathrm{Mg}$ & $\mathrm{Fe}$ & $\mathrm{Na}$ & $\mathrm{Ti}$ & $\mathrm{O}$ & $\mathrm{XFe}^{3}+$ & $\mathrm{XH}_{2} \mathrm{O}$ \\
\hline Dry & 0.00 & 53.26 & 15.67 & 9.93 & 12.11 & 8.63 & 8.16 & 1.03 & 0.500 & 0.12 & 0 \\
\hline Wet & 14.82 & 49.30 & 14.51 & 9.19 & 11.22 & 7.99 & 7.55 & 0.95 & 0.477 & & 1 \\
\hline SS & 7.41 & 51.28 & 15.09 & 9.56 & 11.66 & 8.31 & 7.85 & 0.99 & 0.49 & & 0.5 \\
\hline LOI & 8.89 & 51.68 & 15.20 & 9.63 & 11.75 & 8.37 & 7.91 & 0.99 & 0.49 & & 0.6 \\
\hline Dry & 0.00 & 53.09 & 15.62 & 9.89 & 12.08 & 8.60 & 8.13 & 1.02 & 0.818 & 0.19 & 0 \\
\hline Wet & 14.78 & 49.16 & 14.46 & 9.16 & 11.18 & 7.97 & 7.53 & 0.95 & 0.76 & & 1 \\
\hline SS & 7.39 & 51.13 & 15.04 & 9.53 & 11.63 & 8.28 & 7.83 & 0.99 & 0.79 & & 0.5 \\
\hline LOI & 8.87 & 51.52 & 15.16 & 9.60 & 11.72 & 8.35 & 7.89 & 0.99 & 0.79 & & 0.6 \\
\hline Dry & 0.00 & 52.95 & 15.58 & 9.87 & 12.04 & 8.58 & 8.11 & 1.02 & 1.07 & 0.25 & 0 \\
\hline Wet & 14.74 & 49.05 & 14.43 & 9.14 & 11.16 & 7.95 & 7.51 & 0.95 & 0.995 & & 1 \\
\hline SS & 6.93 & 50.88 & 14.97 & 9.48 & 11.57 & 8.24 & 7.79 & 0.98 & 1.03 & & 0.47 \\
\hline LOI & 8.85 & 51.39 & 15.12 & 9.58 & 11.69 & 8.33 & 7.87 & 0.99 & 1.04 & & 0.6 \\
\hline
\end{tabular}

Abbreviations: LOI, loss on ignition; MSWD, mean square of weighted deviates; P, probability density fit; SS, unsaturated subsolidus water content; TGA, total gas age.

http://dtinkham.net/peq.html, last accessed on 15 April 2019). For all calculations, we used the tc62 database of Holland and Powell (2011) with the following activity-composition relation: amphibole, clinopyroxene, and melt (Green et al., 2016); garnet, orthopyroxene, ilmenite, and biotite (White et al., 2014; epidote (Holland \& Powell, 2011); spinel (White et al., 2002); and plagioclase (Holland \& Powell, 2003). We selected sample AN1709a for further thermobarometric investigation for two main reasons. First, it has reduced variance due to the presence of clinopyroxene, making the assemblage more restrictive. Second, it comes from an in situ location. Using the value reported in the literature for similar amphibolite, we arbitrarily fixed values of $\mathrm{XFe}^{3+}$ to $0.12,0.19$, and 0.25 (with $\mathrm{XFe}^{3+}=\mathrm{Fe}^{3+} /\left[\mathrm{Fe}^{3+}+\mathrm{Fe}^{2+}\right]$ ). These values of $\mathrm{XFe}^{3+}$ are similar to the range reported in Green et al. (2016) for the calibration of the amphibole, clinopyroxene, and melt models. We calculated multiple $\mathrm{T}-\mathrm{XH}_{2} \mathrm{O}$ diagram with the fixed $\mathrm{XFe}^{3+}$ to investigate the water content. The $\mathrm{XH}_{2} \mathrm{O}$ value varies from 0 to 1 (i.e., from dry rock to excess water). It corresponds to a normalized variation of $\mathrm{MH}_{2} \mathrm{O}=0$ to $\mathrm{MH}_{2} \mathrm{O}=7.41 \mathrm{~mol} \%$ in the case of the modeled sample for $\mathrm{XFe}^{3+}=0.12$ (Table 4). When calculating a $\mathrm{T}-\mathrm{XH}_{2} \mathrm{O}$ diagram, we set the pressure to $0.8 \mathrm{Gpa}$ in agreement with our results from the amphibole-plagioclase empirical thermometry and barometry.

For all calculations, the solidus lies at conditions similar to what is shown in Palin et al. (2016) for a midocean ridge basalt composition, and the stable mineral assemblages are similar at first order. The increase of the $\mathrm{Fe}^{3+}$ content has a minimal effect on its position except at low water content where it shifts toward higher temperatures (see the position of the solidus line on the T- $\mathrm{XH}_{2} \mathrm{O}$ section of Figures $6 \mathrm{c}$ and $6 \mathrm{~d}$ ). With $\mathrm{XFe}^{3+}=0.12$, the observed assemblage cannot be modeled (amphibole + clinopyroxene + plagioclase + quartz + rutile + ilmenite; rutile is not predicted in the diagram). A narrow field corresponding to the observed assemblage without rutile lies at $\mathrm{XH}_{2} \mathrm{O}$ between 0.45 and 0.5 with temperature varying between $550{ }^{\circ} \mathrm{C}$ and $800{ }^{\circ} \mathrm{C}$ (Figure 6b). With increasing water content, titanite becomes stable. We then calculated two PT pseudosections. We assume the first one with $\mathrm{XH}_{2} \mathrm{O}=0.5$ (i.e., that allows to compute an assemblage that is near to the one observed) to represent near PT peak conditions where rutile and ilmenite are costable in our sample. In the PT space, the observed assemblage appears in a relatively large field ranging from 0.85 to $1.1 \mathrm{Gpa}$ and between $600{ }^{\circ} \mathrm{C}$ and $725^{\circ} \mathrm{C}$. It is limited toward high temperature by the solidus, toward high pressure by the appearance of garnet and the destabilization of ilmenite, and toward low pressure by the destabilization of rutile. The modal proportion of all phases is close enough to what is observed in the samples ( $>50 \%$ amphibole, $35 \%$ plagioclase, $5-10 \%$ clinopyroxene, and $\sim 5 \%$ rutile and ilmenite). We calculated a second pseudosection with a water content corresponding on the measured loss on ignition $\left(\mathrm{XH}_{2} \mathrm{O}=0.6\right)$. In this calculation, the solidus reaction shifts toward low temperature and lies around $650{ }^{\circ} \mathrm{C}$ at $0.8 \mathrm{GPa}$. Neither rutile nor ilmenite is predicted to be stable at supra solidus conditions except at pressure below $0.6 \mathrm{GPa}$ where ilmenite is stable. We observe a field where titanite is stable together with amphibole, clinopyroxene, plagioclase, and quartz. This corresponds to the observation from our thin section where titanite is overgrowing rutile and or rutile + ilmenite and is stable with amphibole, plagioclase, and clinopyroxene. 
With $\mathrm{XFe}^{3+}=0.19$ (Figure 6c), the observed assemblage can be found at conditions where $\mathrm{XH}_{2} \mathrm{O}$ equals 0.47 at $675{ }^{\circ} \mathrm{C}$. We used the same approach as previously mentioned and calculated two PT pseudosection for $\mathrm{XH}_{2} \mathrm{O}=0.47$ and $\mathrm{XH}_{2} \mathrm{O}=0.6$ (i.e., the loss on ignition). On the first one, we observe the observed assemblage to lie in a field sharing the same topology as for the $\mathrm{XFe} 3+=0.12$ case but with slightly lower pressure and temperature. With increasing water content, the PT pseudosection shares similarities as with the one calculated for $\mathrm{XFe}^{3+}=0.12$. The $\mathrm{XMg}$ of the modeled clinopyroxene increases to a value of 0.67 . When increasing the $\mathrm{Fe}^{3+}$ content $\left(\mathrm{XFe}^{3+}=0.25\right.$ case; Figure $\left.6 \mathrm{~d}\right)$, we observe very similar topologies either on the $\mathrm{T}-\mathrm{XH}_{2} \mathrm{O}$ diagram or on the PT diagrams with different water quantity. The observed assemblage lies in a field that shifted to slightly lower pressure but higher temperature at $0.9 \mathrm{GPa}$ and $700^{\circ} \mathrm{C}$. We note that the chemistry of minerals tends to be more in agreement with the one observed in the case with $\mathrm{XFe}^{3+}=0.25$ : the $\mathrm{XMg}$ modeled for clinopyroxene rises up to 0.7 in the pseudosection in contrast of the case with $\mathrm{XFe}^{3+}=0.12$ where $\mathrm{XMg}=0.65$. We calculated an additional PT pseudosection with $\mathrm{XFe}^{3+}=0.5$. The observed assemblage is modeled in a similar field, and the XMg the clinopyroxene rises up to 0.77 , but the composition of the ilmenite solution model tends to be pure hematite, excluding this case as a possibility for our PT estimates.

In any case, for the three $\mathrm{XFe}^{3+}$ contents, the observed assemblage lies at similar PT conditions of $675 \pm 50{ }^{\circ} \mathrm{C}$ and $0.9 \pm 0.15$ Gpa that we interpret to represent climax PT condition (Figures 6b-6d). As in the case with $\mathrm{XFe}^{3+}=0.12$, the addition of water in the calculation allows to stabilize titanite together with clinopyroxene, amphibole, and plagioclase. Considering the predicted composition of minerals, we take the case where the oxidation state is maximum $\left(\mathrm{XFe}^{3+}=0.25\right)$ to be more representative of our rock, but we are aware that the $\mathrm{PT}$ condition computed for the observed assemblage does not change much with varying $\mathrm{XFe}^{3+}$.

\section{Discussion}

\subsection{Condition of Formation of the Sole of the Andaman Islands}

In this study, we constrained the condition of formation of the highest-grade metamorphic rocks of the Andaman Islands using empirical thermobarometry and a pseudosection modeling. These rocks formed at $0.9 \mathrm{GPa}$ and $675^{\circ} \mathrm{C}$. These results, and the single observation that the amphibolites are welded to the peridotites of the Andaman ophiolite, are coherent with previously documented metamorphic soles around the world (e.g., Agard et al., 2016). The samples we collected do not witness the highest-grade parts of soles reported elsewhere $\left(\sim 85{ }^{\circ} \mathrm{C}\right.$ and $\sim 1.2 \mathrm{GPa}$; e.g., Agard et al., 2016; Cowan et al., 2014; Dubacq et al., 2019; Plunder et al., 2016; Soret et al., 2017). This may either mean that these highest-grade parts were not accreted in the Andaman case (not all sole localities show the full sequence) or that it may be present elsewhere below the Andaman ophiolite. However, the calculated condition aligns well on the typical warm geothermal gradient that is characteristic of subduction initiation $\left(>20^{\circ} \mathrm{C} / \mathrm{km}\right.$; Casey \& Dewey, 1984; Dewey \& Casey, 2013; Hacker, 1990; Soret et al., 2017). The major uncertainties on our PT estimates are related to the difficulty in estimating the water content and the oxidation state of the rock. We have shown that even with large variation in the $\mathrm{XFe}^{3+}$, the PT estimates are close and remains largely identical when one considers the uncertainties related to the method. Interestingly, the $\mathrm{XFe}^{3+}$ variation does not affect the Ti-bearing phase relation much (Soret et al., 2017). With increasing $\mathrm{XFe}^{3+}$, the PT condition of the observed assemblage shifts slightly to higher temperature $\left(+25^{\circ} \mathrm{C}\right)$ and to lower pressure $(-0.1 \mathrm{GPa})$.

Interestingly, the variation of the water content has an important effect on the phase relation of the Ti-bearing phases, especially for the rutile and or ilmenite-to-titanite transition. We may argue on the basis of our observation and of our models that the water content has changed during the evolutionary history of the rock. In our case, titanite-bearing paragenesis can only be modeled for water content close to the loss on ignition (Figure 6). On the opposite, the rutile-ilmenite paragenesis can only be reproduced with quantities of water lower than the measured loss on ignition. Titanite in our sample is observed as overgrowing rutile and clinopyroxene is destabilized to amphibole. The addition of water in the clinopyroxene-bearing paragenesis could produce a reaction consuming rutile or ilmenite and producing titanite instead (e.g., Cpx + Ilm/ $\left.\mathrm{Rt}+\mathrm{H}_{2} \mathrm{O} \pm \mathrm{Pl}=\mathrm{Hbl}+\mathrm{Ttn}\right)$. The addition of water during the history of the rock is compatible with the general subduction initiation context during which the mantle wedge registers a progressive hydration (Prigent et al., 2018a, 2018b; Soret et al., 2016). Causes of such hydration of the exhuming sole can be linked to the dehydration of later accreted metamorphic sole or dehydration/melting of the sole at deeper level (Agard et al., 2018; Soret et al., 2017). It also means that such addition of water needs to occur while the sole is 
exhuming. The PT condition at which this hydration happened cannot be precisely constrained because the activity-composition model used here is being developed for relatively high temperature rocks (Green et al., 2016). We can, however, eliminate the possibility that titanite developed during the late stages of hydrothermal activity when adularia, carbonates, and actinolite crystalized (Figure $3 \mathrm{~h}$ ). This is justified by the textural relationship where titanite is stable with amphibole (Figure 3f) or clinopyroxene (Figures $3 \mathrm{j}$ and $3 \mathrm{k}$ ).

\subsection{Implication of the Sole Age: Estimating the Duration of Flip Polarity Reversal}

Our two plateau ages of $106.4 \pm 2.1$ and $105.3 \pm 1.6$ Ma obtained for the metamorphic sole are certainly older than the age of previously interpreted ophiolititc crust formation based on the available ages of 93-98 Ma (Bhattacharya et al., 2020; Pedersen et al., 2010; Sarma et al., 2010). The cooling ages of the metamorphic sole obtained by the Ar/Ar method are systematically coeval with the crystallization ages of the ophiolite (e.g., Oman, Hacker, 1994; Turkey, see review in van Hinsbergen et al., 2016; Greece, Dimo-Lahite et al., 2001; Liati et al., 2004). This age is also coeval with the 106-Ma $\mathrm{Ar} / \mathrm{Ar}$ age on plagioclase xenocrysts documented in recent lava flows of the Barren Island and is interpreted as the age of the Andaman ophiolite that is thought to be the basement of the Barren Island (Ray et al., 2015).

In light of the presented results and on data from the literature, we propose the following revised scenario for the formation and evolution of the Andaman ophiolites and provide estimates on the duration of a subduction polarity reversal that we interpret to be the result of the Woyla-Sundaland arc-continent collision (Figure 7).

1. By approximately $120 \mathrm{Ma}$, the conceptual Ngalau Plate was consumed in a double-verging subduction system (Advokaat et al., 2018; Barber et al., 2005). This resulted in the development of the intra oceanic Woyla Arc and of the Western Sumatra Arc on Sundaland (Figure 7a). This is attested by the 122- to 105-Ma ages of the volcanic rocks in the Woyla Arc (Gafoer et al., 1993; Koning, 1985) and the assemblage of mid-Jurassic to Upper Cretaceous sediments and intrusive rocks in the Western Sumatra Arc (Advokaat et al., 2018; Barber et al., 2005; Zhang et al., 2019).

2. While the triple junction was moving, southwards, the Woyla Arc or island arc generated above the subduction zones collided with Eurasia. It leads to the southwards propagation of subduction initiation toward the back-arc basin behind the Woyla Arc (Figure 7b). The back-arc basin is a good candidate for the propagation of the subduction zone as it represents a global mechanical weakness where subduction can nucleate (e.g., Beaussier et al., 2019, 2018). Whether the ridge itself or another structure/weakness is the place where subduction initiates remains, however, speculative. Meanwhile, arc volcanism continued on both sides of the Ngalau Plate (i.e., in the Western Sumatra and Woyla arcs), showing that arc collision there was not underway yet.

3. We interpret the approximately 105-Ma Ar/Ar age on amphibole as a cooling age. It means that by $\sim 105 \mathrm{Ma}$, the metamorphic sole of the Andaman Islands was exhuming (Figure 7c). This is coeval with the $106 \mathrm{Ma} \mathrm{Ar} / \mathrm{Ar}$ age on plagioclase xenocrysts of the Barren Island volcanic rocks (Ray et al., 2015) interpreted to represent the formation of the Andaman ophiolite The Woyla Arc and Western Sumatra Arc enter their final stages but are still active (Gafoer et al., 1993; Koning, 1985; Zhang et al., 2019).

4. From at least $95 \mathrm{Ma}$ onwards, a true magmatic arc became active above the newly formed NE-dipping subduction (Figure 7d). This activity is attested by (i) 93-Ma plagiogranite with an arc affinity intruding the ophiolite (Jafri et al., 1995; Sarma et al., 2010) and (ii) by agglomerates (arc volcanic pyroclastic deposits), among which some include 95-Ma plagiogranite components dated by Pedersen et al. (2010). These ages are considerably younger than the cooling ages of the Andaman metamorphic sole and demonstrate that the subduction was fully developed by that time (Figure 7d). This also would implies that a significant part of magmatic and mantle rocks previously considered as the Andaman ophiolite is actually the expression on an arc emplaced in the ophiolite (Figure 7d). The Woyla Arc is then accreted to Sundaland once the Ngalau Plate was entirely consumed (Figure 7d; Advokaat et al., 2018). Magmatism on the Western Sumatra Arc occurs until at least $85 \mathrm{Ma}$ in the southernmost part (Zhang et al., 2019) and could have stopped earlier to the north (Wang et al., 2014). 

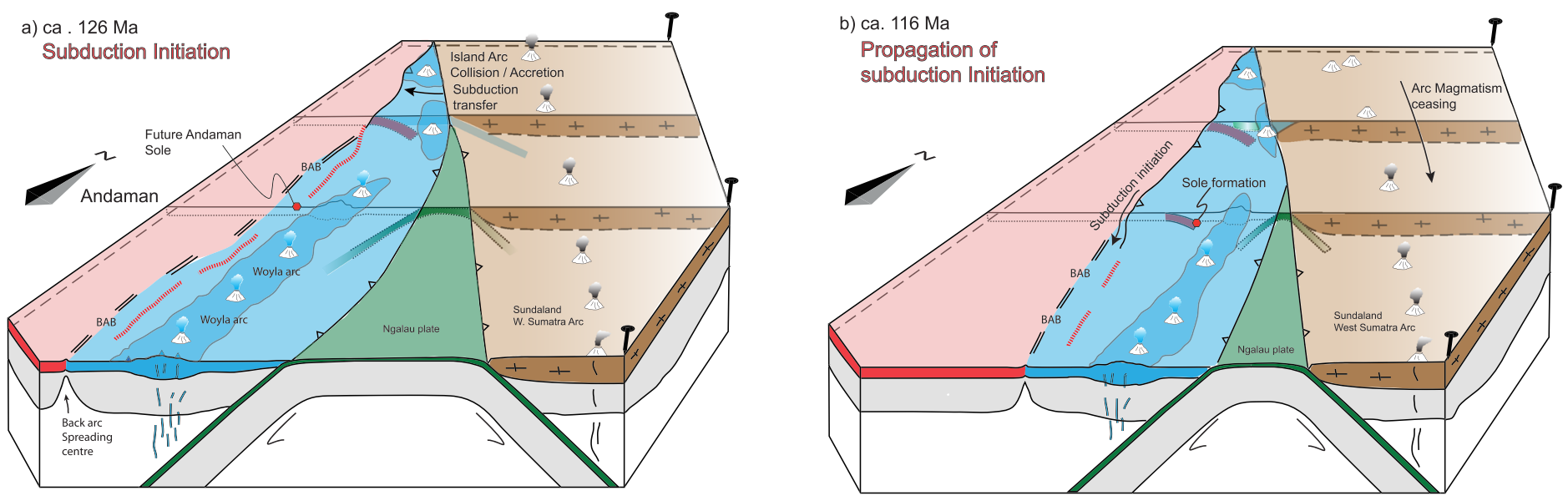

c) ca. $106 \mathrm{Ma}$

Wyola arc collision

SSZ Ophiolite spreading

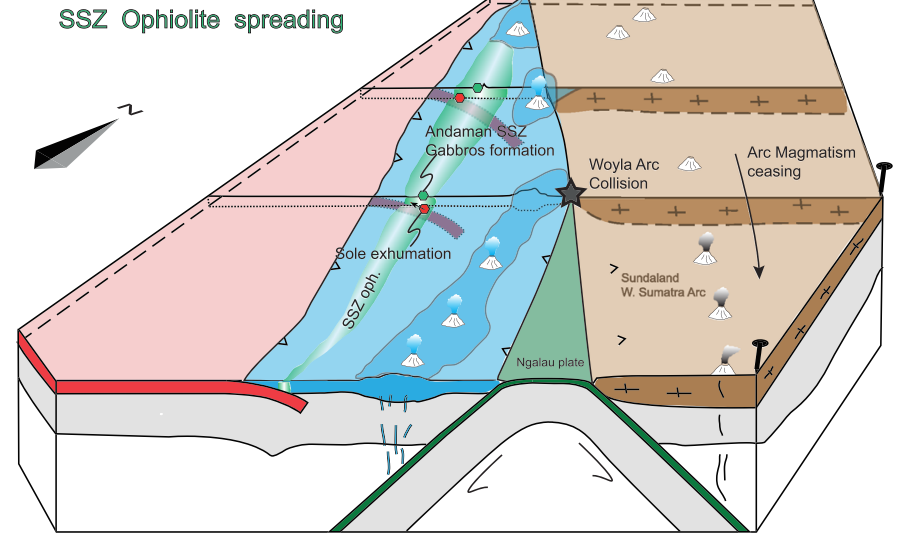

d) ca. $95 \mathrm{Ma}$

Agglomerate intruding ophiolite \& associated volcanism

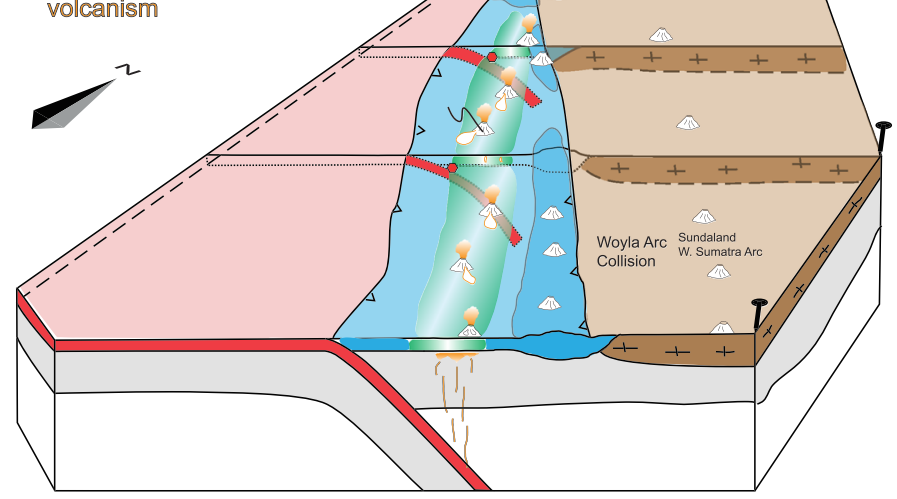

Figure 7. Tentative geodynamic reconstruction of the Andaman ophiolite. (a) Approximately $126 \mathrm{Ma}$ initiation of a new subduction zone upon collision of the northern extension of the Woyla Arc. The Ngalau Plate is consuming on both sides (Advokaat et al., 2018), and arc magmatism exists on both Sundaland and Woyla arcs. (b) Approximately 116 Ma: the new subduction zone propagates southwards. Arc magmatism on Sundaland ceases in the northern part (Lin

et al., 2019). (c) Approximately 106 Ma: The gray star indicates the moment when the northernmost part of the Woyla Arc starts to collide with Sundaland. At that time, the Andaman metamorphic sole is exhuming (our data), and SSZ gabbros are crystallizing. (d) Approximately 95 Ma, arc magmatism starts above the new north-eastward dipping subduction as attested by the agglomerates of the Andaman Islands. Most of the Woyla Arc is accreted to Sundaland (Advokaat et al., 2018). The BAB abbreviation shows the approximate location the back-arc basin. Dotted red line denotes the weak place where the new subduction will start. Double lines show the position of the back-arc spreading center.

All in all, this scenario allows us to evaluate the duration of subduction polarity reversal in context of the Woyla Arc-Sundaland collision. We use the age of the sole likely representing exhumation as a minimum age for subduction initiation. In other settings, sole exhumation ages are coeval with the ages of SSZ ophiolite formation (Hacker, 1994; van Hinsbergen et al., 2015, and reference therein). In the case of the Andaman Islands, the age we obtained for the metamorphic sole are older than any direct evidence from the ophiolite but coeval with the proposed age of the ophiolite (Ray et al., 2015). This would require further investigation on the age of formation of the agglomerates and ophiolititc rock of the Andaman Islands. The formation of part of the present-day ophiolite occurred $\sim 10 \mathrm{Myr}$ prior to the formation of the 95- to 93-Ma new magmatic arc sequence that formed in and on the ophiolite (Figure 7d). This gives us a minimum 10-Myr duration for subduction polarity reversal. However, it is reasonable to argue that subduction initiation must have predated the cooling of the sole. The delay between prograde metamorphism dated using Lu-Hf ages on garnet and exhumation ages documented by $\mathrm{Ar} / \mathrm{Ar}$ ages on amphibole in other sole locations in western Turkey and Oman (Guilmette et al., 2018; Pourteau et al., 2019) is as much as 8-12 Myr. It means that subduction might have initiated as early as approximately $115 \mathrm{Ma}$ on the Andaman transect. Combining that with the minimum duration, it allows us to speculate that subduction reversal occurs at least over 18-22 Myr. 
This time span is consistent with timing proposed for other subduction polarity reversals, such as $22 \mathrm{Myr}$ documented from the sedimentary record in th Dominican Republic and Puerto Rico (in the Caribbean region; Lebron \& Perfit, 1993), 10-22 Myr on the basis of geochronological data from the Irish Caledonides (Clift et al., 2003), 12 Myr from the age of porphyry copper deposit in the South West Pacific (Solomon, 1990), and is in the same range as the subduction polarity reversal documented below Taiwan (Clift et al., 2003; von Hagke et al., 2016). From these examples, subduction polarity reversal may last tens of millions year, depending most likely on the plate convergence rate and on the geometry of the plate boundary system and the obliquity between the colliding arc and continent. Subduction polarity reversal is likely to be a gradual, three-dimensional process that takes tens of million years on a given transect. The Andaman Islands setting may thus provide a test case for thermomechanical numerical model studies on the dynamics of subduction initiation through polarity reversal in response to arc-continent collision. Further test would be to investigate the velocity of subduction initiation propagation that Zhou et al. (2018) propose to be in the order of 10-20 cm/year and to test whether the ridge or other structures in the back-arc basin is the key location for subduction initiation.

\section{Conclusions}

We here provide the estimation of the duration of a subduction polarity reversal during arc-continent collision that occurred during the Late Cretaceous. Using the case study of the Andaman Islands, we constrained the timing of subduction initiation by a petrochronological study of the metamorphic sole. The sole formed at $0.95 \mathrm{GPa}$ and $675^{\circ} \mathrm{C}$ and was exhumed no later than approximately $105 \mathrm{Ma}$ as constrained by two new $\mathrm{Ar} / \mathrm{Ar}$ ages on hornblende. The geochemistry of the metamorphic sole fits with a back-arc basin origin close to the Woyla Arc, when that collided with Sundaland, in agreement with existing paleogeographic reconstructions, an ideal place for subduction initiation. Altogether, our petrochronological and field data together with literature review advocate for a subduction polarity reversal following the diachronous collision of the Woyla Arc with Sundaland. We may estimate that subduction polarity reversal has occurred on time scales of at least 10 Myr. The well-constrained Andaman Islands case study could serve for further investigation of subduction polarity reversal as a fundamental mechanism to create new subduction zones.

\section{References}

\section{Acknowledgments}

A. P., D. J. J. v. H. and E. L. A. were funded through European Research Council starting grant SINK (306810) to D. J. J. v. H. D. J. J. v. H. acknowledges NWO Vici grant 865.17.001. D. B. acknowledges the support of DST INSPIRE Fellowship (IF 130148). B. G. acknowledges financial support received from Science and Engineering Research Board, DST, India (EMR/ 2017/000929). We thank the Ramakrishna mission in Port-Blair for accommodation and Yael Engbers for help during the fieldwork. We thank two anonymous reviewers and Osman Parlak for constructive comments. We thank J. Geissman and Y. Eyüboğlu for editorial handling. We are indebted to Loes van Unnik Hoorn, N. Rividi, and M. Fialin at the Camparis service in Paris and to T. Bouten and S. Maatvev at the GeoLab in Utrecht for help during microprobe session. All raw probe data are accessible at the following data repository: https://figshare.com/articles/2019TC005762R_Raw_Probe_ Data_xlsx/11890233.
Advokaat, E. L., Bongers, M. L. M., Rudyawan, A., BouDagher-Fadel, M. K., Langereis, C. G., \& van Hinsbergen, D. J. J. (2018). Early Cretaceous origin of the Woyla Arc (Sumatra, Indonesia) on the Australian Plate. Earth and Planetary Science Letters, 498, 348-361. https://doi.org/10.1016/j.epsl.2018.07.001

Agard, P., Plunder, A., Angiboust, S., Bonnet, G., \& Ruh, J. (2018). The subduction plate interface: Rock record and mechanical coupling (from long to short timescales). Lithos, 320-321, 537-566. https://doi.org/10.1016/j.lithos.2018.09.029

Agard, P., Yamato, P., Soret, M., Prigent, C., Guillot, S., Plunder, A., et al. (2016). Subduction infancy: Mantle resistance to slab penetration and metamorphic sole formation controlled by plate interface rheological switches. Earth and Planetary Science Letters, 451, 208-220. https://doi.org/10.1016/j.epsl.2016.06.054

Baldwin, S. L., Harrison, T. M., \& Fitz, G. J. D. (1990). Diffusion of (super 40) Ar in metamorphic hornblende. Contributions to Mineralogy and Petrology, 105(6), 691-703. Retrieved from. https://link.springer.com/article/10.1007/BF00306534

Bandopadhyay, P. C. (2012). Re-interpretation of the age and environment of deposition of Paleogene turbidites in the Andaman and Nicobar Islands, Western Sunda Arc. Journal of Asian Earth Sciences, 45, 126-137. https://doi.org/10.1016/j.jseaes.2011.08.018

Bandopadhyay, P. C., \& Carter, A. (2017a). Introduction to the geography and geomorphology of the Andaman-Nicobar Islands. Geological Society, London, Memoirs, 47(1), 9-18. https://doi.org/10.1144/M47.2

Bandopadhyay, P. C., \& Carter, A. (2017b). Submarine fan deposits: Petrography and geochemistry of the Andaman Flysch. Geological Society, London, Memoirs, 47(1), 133-140. https://doi.org/10.1144/M47.9

Bandyopadhyay, D., Ghosh, B., Guilmette, C., Plunder, A., Corfu, F., Advokaat, E. L.. Clue to the Cretaceous subduction initiation in South-East Asia-A geochronological and geochemical perspective from Andaman ophiolite. Geochemistry, Geophysics, Geosystems.

Bandyopadhyay, D., van Hinsbergen, D. J. J., Plunder, A., Bandopadhyay, P. C., Advokaat, E. L., Morishita, T., \& Ghosh, B. (2020). Andaman ophiolites: An overview. In J. S. Ray, \& M. Radhakrishna (Eds.), The Andaman Islands and adjoining offshore: Geology, tectonics and paleoclimate (Chap. 1, pp. 1-17). Springer Nature Switzerland AG 2020. https://doi.org/10.1007/978-3-030-39843-9_1

Bhattacharya, S., Pande, K., Kumar, A., Kingson, O., \& Ray, J. S. (2020). Timing of Formation and Obduction of the Andaman Ophiolite BT - The Andaman Islands and Adjoining Offshore: Geology, Tectonics and Palaeoclimate. In Jyotiranjan S Ray \& M. Radhakrishna (Eds.) (pp. 19-42). Cham: Springer International Publishing. https://doi.org/10.1007/978-3-030-39843-9_2

Barber, A. J., Crow, M. J., \& De Smet, M. E. M. (2005). Chapter 14 tectonic evolution. Geological Society, London, Memoirs, 31(1), $234-259$. https://doi.org/10.1144/GSL.MEM.2005.031.01.14

Beaussier, S. J., Gerya, T. V., \& Burg, J. P. (2019). Near-ridge initiation of intraoceanic subduction: Effects of inheritance in 3D numerical models of the Wilson cycle. Tectonophysics, 763(November 2018), 1-13. https://doi.org/10.1016/j.tecto.2019.04.011

Beaussier, S. J., Gerya, T. V., \& Burg, J.-P. (2018). 3D numerical modelling of the Wilson cycle: Structural inheritance of alternating subduction polarity. Geological Society, London, Special Publications, SP470.15. https://doi.org/10.1144/sp470.15

Breen, N. A., Silver, E. A., \& Roof, S. (1989). The Wetar Back Arc Thrust Belt, eastern Indonesia: The effect of accretion against an irregularly shaped arc. Tectonics, 8(1), 85-98. https://doi.org/10.1029/TC008i001p00085 
Casey, J. F., \& Dewey, J. F. (1984). Initiation of subduction zones along transform and accreting plate boundaries, triple-junction evolution, and forearc spreading centres-Implications for ophiolitic geology and obduction. Geological Society, London, Special Publications, 13(1), 269-290. https://doi.org/10.1144/GSL.SP.1984.013.01.22

Cerny, P., \& Chapman, R. (1986). Adularia from hydrothermal vein deposits: Extremes in structural state. Canadian Mineralogist, 24(4), 717-728.

Chemenda, A. I., Yang, R.-K., Stephan, J.-F., Konstantinovskaya, E. A., \& Ivanov, G. M. (2001). New results from physical modelling of arc-continent collision in Taiwan: Evolutionary model. Tectonophysics, 333(1-2), 159-178. https://doi.org/10.1016/S0040-1951(00) 00273-0

Clift, P. D., Schouten, H., \& Draut, A. E. (2003). A general model of arc-continent collision and subduction polarity reversal from Taiwan and the Irish Caledonides. Geological Society, London, Special Publications, 219(1), 81-98. https://doi.org/10.1144/GSL. SP.2003.219.01.04

Cooper, P., \& Taylor, B. (1987). Seismotectonics of New Guinea: A model for arc reversal following arc-continent collision. Tectonics, 6(1), 53-67. https://doi.org/10.1029/TC006i001p00053

Cooper, P. A., \& Taylor, B. (1985). Polarity reversal in the Solomon Islands Arc. Nature, 314(6010), 428-430. https://doi.org/10.1038/ $314428 \mathrm{a} 0$

Cowan, R. J., Searle, M. P., \& Waters, D. J. (2014). Structure of the metamorphic sole to the Oman ophiolite, Sumeini window and Wadi Tayyin: Implications for ophiolite obduction processes. Geological Society, London, Special Publications, 392(1), 155-175. https://doi.org/ $10.1144 /$ SP392.8

Curray, J. R. (1989). The Sunda Arc: A model for oblique plate convergence. Netherlands Journal of Sea Research, 24(2-3), 131-140. Retrieved from. https://www.sciencedirect.com/science/article/pii/0077757989901440, https://doi.org/10.1016/0077-7579(89)90144-0

Curray, J. R. (2005). Tectonics and history of the Andaman Sea region. Journal of Asian Earth Sciences, 25(1), 187-232. https://doi.org/ 10.1016/j.jseaes.2004.09.001

de Capitani, C., \& Brown, T. H. (1987). The computation of chemical equilibrium in complex systems containing non-ideal solutions. Geochimica et Cosmochimica Acta, 51(10), 2639-2652. https://doi.org/10.1016/0016-7037(87)90145-1

de Capitani, C., \& Petrakakis, K. (2010). The computation of equilibrium assemblage diagrams with Theriak/Domino software. American Mineralogist, 95(7), 1006-1016. https://doi.org/10.2138/am.2010.3354

Dewey, J. F. (1976). Ophiolite obduction. Tectonophysics, 31(1-2), 93-120. https://doi.org/10.1016/0040-1951(76)90169-4

Dewey, J. F., \& Casey, J. F. (2013). The sole of an ophiolite: The Ordovician Bay of islands complex, Newfoundland. Journal of the Geological Society, London, 170(5), 715-722. https://doi.org/10.1144/jgs2013-017

Dickinson, W. R. (1973). Widths of modern arc-trench gaps proportional to past duration of igneous activity in associated magmatic arcs Journal of Geophysical Research, 78(17), 3376-3389. https://doi.org/10.1029/jb078i017p03376

Dimo-Lahite, A., Monié, P., \& Vergély, P. (2001). Metamorphic soles from the Albanian ophiolites: Petrology, ${ }^{40} \mathrm{Ar} /{ }^{39} \mathrm{Ar}$ geochronology, and geodynamic evolution. Tectonics, 20(1), 78-96. https://doi.org/10.1029/2000TC900024

Domeier, M., Shephard, G. E., Jakob, J., Gaina, C., Doubrovine, P. V., \& Torsvik, T. H. (2017). Intraoceanic subduction spanned the Pacific in the Late Cretaceous-Paleocene. Science Advances, 3(11), 1, eaao2303-6. https://doi.org/10.1126/sciadv.aao2303

Dubacq, B., Soret, M., Jewison, E., \& Agard, P. (2019). Early subduction dynamics recorded by the metamorphic sole of the Mt. Albert ophiolitic complex (Gaspé Quebec). Lithos, 334-335, 161-179. https://doi.org/10.1016/j.lithos.2019.03.019

Ernst, W. G., \& Liu, J. (1998). Experimental phase-equilibrium study of Al- and Ti-contents of calcic amphibole in MORB-A semiquantitative thermobarometer. American Mineralogist, 83(9-10), 952-969. https://doi.org/10.2138/am-1998-9-1004

Faccenda, M., Gerya, T. V., \& Chakraborty, S. (2008). Styles of post-subduction collisional orogeny: Influence of convergence velocity, crustal rheology and radiogenic heat production. Lithos, 103(1-2), 257-287. https://doi.org/10.1016/j.lithos.2007.09.009

Fareeduddin, \& Dilek, Y. (2015). Structure and petrology of the Nagaland-Manipur Hill Ophiolitic Mélange zone, NE India: A fossil Tethyan subduction channel at the India-Burma Plate boundary. Episodes, (December), 298-314. https://doi.org/10.18814/epiiugs/ 2015/v38i4/82426

Gafoer, S., Amin, T. C., \& Pardede, R. (1993). Geology of the Bengkulu Quadrangle, Sumatra, scale 1: 250.000. Geological Research and Development Centre, Bandung.

Ghosh, B., Bandyopadhyay, D., \& Morishita, T. (2017). Chapter 7 Andaman-Nicobar ophiolites, India: Origin, evolution and emplacement. Geological Society, London, Memoirs, 47(1), 95 LP - 110) Retrieved from. http://mem.lyellcollection.org/content/47/1/95.abstract, https://doi.org/10.1144/M47.7

Ghosh, B., Morishita, T., Gupta, B. S., Tamura, A., Arai, S., \& Bandyopadhyay, D. (2014). Moho transition zone in the Cretaceous Andaman ophiolite, India: A passage from the mantle to the crust. Lithos, 198-199(1), 117-128. https://doi.org/10.1016/j.lithos.2014.03.027

Ghosh, B., Pal, T., Bhattacharya, A., \& Das, D. (2009). Petrogenetic implications of ophiolitic chromite from Rutland Island, Andaman-A boninitic parentage in supra-subduction setting. Mineralogy and Petrology, 96(1-2), 59-70. https://doi.org/10.1007/s00710-008-0039-9

Gill, J. B. (1981). Orogenic andesites and plate tectonics, (Vol. 16). Berlin, Heidelberg: Springer Berlin Heidelberg. https://doi.org/10.1007/ 978-3-642-68012-0

Green, E. C. R., White, R. W., Diener, J. F. A., Powell, R., Holland, T. J. B., \& Palin, R. M. (2016). Activity-composition relations for the calculation of partial melting equilibria for metabasic rocks. Journal of Metamorphic Geology, 1-25. https://doi.org/10.1017/ CBO9781107415324.004

Guilmette, C., Smit, M. A., van Hinsbergen, D. J. J., Gürer, D., Corfu, F., Charette, B., et al. (2018). Forced subduction initiation recorded in the sole and crust of the Semail Ophiolite of Oman. Nature Geoscience, 11(9), 688-695. https://doi.org/10.1038/s41561-018-0209-2

Hacker, B. R. (1990). Simulation of the metamorphic and deformational history of the metamorphic sole of the Oman ophiolite. Journal of Geophysical Research, 95(B4), 4895. https://doi.org/10.1029/JB095iB04p04895

Hacker, B. R. (1994). Rapid emplacement of young oceanic lithosphere: Argon geochronology of the Oman ophiolite. Science, 265(5178), 1563-1565. https://doi.org/10.1126/science.265.5178.1563

Hall, R. (2002). Cenozoic geological and plate tectonic evolution of SE Asia and the SW Pacific: Computer-based reconstructions, model and animations. Journal of Asian Earth Sciences, 20(4), 353-431. https://doi.org/10.1016/S1367-9120(01)00069-4

Hall, R. (2012). Late Jurassic-Cenozoic reconstructions of the Indonesian region and the Indian Ocean. Tectonophysics, 570-571, 1-41. https://doi.org/10.1016/j.tecto.2012.04.021

Harris, R. (2006). Rise and fall of the Eastern Great Indonesian Arc recorded by the assembly, dispersion and accretion of the Banda Terrane, Timor. Gondwana Research, 10(3-4), 207-231. https://doi.org/10.1016/J.GR.2006.05.010

Harrison, M. T. (1982). Diffusion of ${ }^{40} \mathrm{Ar}$ in hornblende. Contributions to Mineralogy and Petrology, 78(3), 324-331. https://doi.org/10.1007/ BF00398927 
Holland, T., \& Blundy, J. (1994). Non-ideal interactions in calcic amphiboles and their bearing on amphibole-plagioclase thermometry. Contributions to Mineralogy and Petrology, 116(4), 433-447. https://doi.org/10.1007/BF00310910

Holland, T., \& Powell, R. (2003). Activity-compositions relations for phases in petrological calculations: An asymmetric multicomponent formulation. Contributions to Mineralogy and Petrology, 145(4), 492-501. https://doi.org/10.1007/s00410-003-0464-z

Holland, T. J. B., \& Powell, R. (2011). An improved and extended internally consistent thermodynamic dataset for phases of petrological interest, involving a new equation of state for solids. Journal of Metamorphic Geology, 29(3), 333-383. https://doi.org/10.1111/ j.1525-1314.2010.00923.x

Jafri, S. H., Charan, S. N., \& Govil, P. K. (1995). Plagiogranite from the Andaman ophiolite belt, Bay of Bengal, India. Journal of the Geological Society, 152(4), 681-687. https://doi.org/10.1144/gsjgs.152.4.0681

Jafri, S. H., Subba Rao, M. V., \& Ramesh, S. L. (2006). Occurrence of ash beds in radiolarian cherts from South Andaman Island, Bay of Bengal, India: Evidence for Late Cretaceous explosive volcanism. Current Science, 91(12), 1614-1615.

Jamieson, R. A. (1986). P-T paths from high temperature shear zones beneath ophiolites. Journal of Metamorphic Geology, 4(1), 3-22. https://doi.org/10.1111/j.1525-1314.1986.tb00335.x

Jørgensen, T. R. C., Tinkham, D. K., \& Lesher, C. M. (2019). Low-P and high-T metamorphism of basalts: Insights from the Sudbury impact melt sheet aureole and thermodynamic modelling. Journal of Metamorphic Geology, 37(2), 271-313. https://doi.org/10.1111/ jmg. 12460

Knesel, K. M., Cohen, B. E., Vasconcelos, P. M., \& Thiede, D. S. (2008). Rapid change in drift of the Australian plate records collision with Ontong Java Plateau. Nature, 454(7205), 754-757. https://doi.org/10.1038/nature07138

Koning, T. (1985). Petroleum geology of the Ombilin Intermontane Basin, West Sumatra. Indonesian Petroleum Association, 14th Annual Convention Proceedings, 1, 117-137.

Konstantinovskaia, E. (2001). Arc-continent collision and subduction reversal in the Cenozoic evolution of the Northwest Pacific: An example from Kamchatka (NE Russia). Tectonophysics, 333(1-2), 75-94. https://doi.org/10.1016/S0040-1951(00)00268-7

Leake, B. E., Woolley, A. R., Arps, C. E. S., Birch, W., Gilbert, C., Grice, J., Hawthorne, E., Kato, A., Kisch, H. J., Krivovichev, V. G., Linthout, K., Laird, J., Mandarino, J., Nickel, E. H., Rock, N. M. S., Schumacher, J. C., Smith, D. C., Stephenson, N. C. N., Ungaretti, L., Whittaker, E. J. W., \& Youzhi, G. (1997). Nomenclature of amphiboles: Report of the subcommittee on amphiboles of the international mineralogical association, commission on new minerals and mineral names. European Journal of Mineralogy, 9(3), 623-651. https://doi. $\operatorname{org} / 10.1127 /$ ejm/9/3/0623

Lebron, M. C., \& Perfit, M. R. (1993). Stratigraphic and petrochemical data support subduction polarity reversal of the Cretaceous Caribbean Island Arc. The Journal of Geology, 101(3), 389-396. https://doi.org/10.1086/648231

Lee, J.-Y., Marti, K., Severinghaus, J. P., Kawamura, K., Yoo, H.-S., Lee, J. B., \& Kim, J. S. (2006). A redetermination of the isotopic abundances of atmospheric Ar. Geochimica et Cosmochimica Acta, 70(17), 4507-4512. https://doi.org/10.1016/J.GCA.2006.06.1563

Liati, A., Gebauer, D., \& Fanning, C. M. (2004). The age of ophiolitic rocks of the Hellenides (Vourinos, Pindos, Crete): First U-Pb ion microprobe (SHRIMP) zircon ages. Chemical Geology, 207(3-4), 171-188. https://doi.org/10.1016/j.chemgeo.2004.02.010

Lin, T.-H., Mitchell, A. H. G., Chung, S.-L., Tan, X.-B., Tang, J.-T., Oo, T., \& Wu, F.-Y. (2019). Two parallel magmatic belts with contrasting isotopic characteristics from southern Tibet to Myanmar: Zircon U-Pb and Hf isotopic constraints. Journal of the Geological Society, 176(3), 574-587. https://doi.org/10.1144/jgs2018-072

Ling, H. Y., Chandra, R., \& Karkare, S. G. (1996). Tectonic significance of Eocene and Cretaceous radiolaria from South Andaman Island, northeast Indian Ocean. Island Arc, 5(2), 166-179. https://doi.org/10.1111/j.1440-1738.1996.tb00023.x

Ling, H. Y., \& Srinivasan, S. (1993). Significance of Eocene radiolaria from Port Blair group of South Andaman Island, India. Journal of the Paleontological Society of India, 38, 1-5.

Liu, C. Z., Chung, S. L., Wu, F. Y., Zhang, C., Xu, Y., Wang, J. G., et al. (2016). Tethyan suturing in Southeast Asia: Zircon U-Pb and Hf-O isotopic constraints from Myanmar ophiolites. Geology, 44(4), 311-314. https://doi.org/10.1130/G37342.1

Mccaffrey, R. (1992). Oblique plate convergence, slip vectors, and forearc deformation. Journal of Geophysical Research, 97(B6), 8905-8915. https://doi.org/10.1029/92JB00483

McCaffrey, R. (2009). The tectonic framework of the Sumatran subduction zone. Annual Review of Earth and Planetary Sciences, 37(1), 345-366. https://doi.org/10.1146/annurev.earth.031208.100212

McDougall, I., \& Harrison, T. M. (1999). Geochronology and thermochronology by the ${ }^{40} A r /{ }^{39} A r$ method (2nd). Oxford: Oxford University Press.

Molina, J. F., Moreno, J. A., Castro, A., Rodríguez, C., \& Fershtater, G. B. (2015). Calcic amphibole thermobarometry in metamorphic and igneous rocks: New calibrations based on plagioclase/amphibole Al-Si partitioning and amphibole/liquid Mg partitioning. Lithos, 232, 286-305. https://doi.org/10.1016/j.lithos.2015.06.027

Pal, T. (2011). Petrology and geochemistry of the Andaman ophiolite: Melt-rock interaction in a suprasubduction-zone setting. Journal of the Geological Society, 168(4), 1031-1045. https://doi.org/10.1144/0016-76492009-152

Pal, T., \& Bhattacharya, A. (2010). Greenschist-facies sub-ophiolitic metamorphic rocks of Andaman Islands, Burma-Java subduction complex. Journal of Asian Earth Sciences, 39(6), 804-814. https://doi.org/10.1016/j.jseaes.2010.05.017

Pal, T., Chakraborty, P. P., Gupta, T. D., \& Singh, C. D. (2003). Geodynamic evolution of the outer-arc-forearc belt in the Andaman Islands, the central part of the Burma-Java subduction complex. Geological Magazine, 140(3), 289-307. https://doi.org/10.1017/ S0016756803007805

Palin, R. M., White, R. W., Green, E. C. R., Diener, J. F. A., Powell, R., \& Holland, T. J. B. (2016). High-grade metamorphism and partial melting of basic and intermediate rocks. Journal of Metamorphic Geology, 34, 871-892. https://doi.org/10.1111/jmg.12212

Parlak, O., Dunkl, I., Karaoğlan, F., Kusky, T. M., Zhang, C., Wang, L., et al. (2019). Rapid cooling history of a Neotethyan ophiolite: Evidence for contemporaneous subduction initiation and metamorphic sole formation. Bulletin of the Geological Society of America, 131 (11-12), 2011-2038. https://doi.org/10.1130/B35040.1

Pearce, J. a., Lippard, S. J., \& Roberts, S. (1984). Characteristics and tectonic significance of supra-subduction zone ophiolites. Geological Society, London, Special Publications, 16(1), 77-94. https://doi.org/10.1144/GSL.SP.1984.016.01.06

Pedersen, R. B., Searle, M. P., Carter, A., \& Bandopadhyay, P. C. (2010). U-Pb zircon age of the Andaman ophiolite: Implications for the beginning of subduction beneath the Andaman-Sumatra arc. Journal of the Geological Society, London, 167(6), 1105-1112. https://doi. org/10.1144/0016-76492009-151

Plunder, A., Bandyopadhyay, D., Ganerød, M., Advokaat, E., Ghosh, B., Bandopadhyay, P., \& van Hinsbergen, D. (2020). Dataset associated to the paper: History of subduction polarity reversal during arc-continent collision: Constraints from the Andaman ophiolite and its metamorphic sole. https://doi.org/10.6084/m9.figshare.11890233.v3 
Plunder, A., Agard, P., Chopin, C., Soret, M., Okay, A. I., \& Whitechurch, H. (2016). Metamorphic sole formation, emplacement and blueschist facies overprint: Early subduction dynamics witnessed by western Turkey ophiolites. Terra Nova, 28(5), 329-339. https://doi. $\operatorname{org} / 10.1111 /$ ter.12225

Pourteau, A., Scherer, E. E., Schorn, S., Bast, R., Schmidt, A., \& Ebert, L. (2019). Thermal evolution of an ancient subduction interface revealed by Lu-Hf garnet geochronology, Halilbağı Complex (Anatolia). Geoscience Frontiers, 10(1), 127-148. https://doi.org/10.1016/j. gsf.2018.03.004

Prigent, C., Agard, P., Guillot, S., Godard, M., \& Dubacq, B. (2018). Mantle wedge (de)formation during subduction infancy: Evidence from the base of the Semail ophiolitic mantle. Journal of Petrology, 59(11), 2061-2092. https://doi.org/10.1093/petrology/egy090

Prigent, C., Guillot, S., Agard, P., \& Ildefonse, B. (2018). Fluid-assisted deformation and strain localization in the cooling mantle wedge of a young subduction zone (Semail ophiolite). Journal of Geophysical Research - Solid Earth, 123(9), 7529-7549. https://doi.org/10.1029/ 2018JB015492

Pysklywec, R. N. (2001). Evolution of subducting mantle lithosphere at a continental plate boundary. Geophysical Research Letters, 28(23), 4399-4402. https://doi.org/10.1029/2001GL013567

Ratheesh Kumar, R. T., Windley, B. F., Rajesh, V. J., \& Santosh, M. (2013). Elastic thickness structure of the Andaman subduction zone: Implications for convergence of the Ninetyeast Ridge. Journal of Asian Earth Sciences, 78, 291-300. https://doi.org/10.1016/j. jseaes.2013.01.018

Ray, J. S., Pande, K., \& Bhutani, R. (2015). ${ }^{40} \mathrm{Ar} /{ }^{39}$ Ar geochronology of subaerial lava flows of Barren Island volcano and the deep crust beneath the Andaman Island Arc, Burma Microplate. Bulletin of Volcanology, 77(6), 1-10. https://doi.org/10.1007/s00445-015-0944-9

Ray, K. (1985). East Coast Volcanics: A new suite in the ophiolite of Andaman Islands. Records of the Geological Survey of India, 116, 83-87.

Ray, K., Sengupta, S., \& van den Hul, H. J. (1988). Chemical characters of volcanic rocks from Andaman ophiolite, India. Journal of the Geological Society, 14(5), 393-400. https://doi.org/10.1144/gsigs.145.3.0393

Renne, P. R., Mundil, R., Balco, G., Min, K., \& Ludwig, K. R. (2010). Joint determination of ${ }^{40} \mathrm{~K}$ decay constants and ${ }^{40} \mathrm{Ar} * /^{40} \mathrm{~K}$ for the Fish Canyon sanidine standard, and improved accuracy for ${ }^{40} \mathrm{Ar} /{ }^{39} \mathrm{Ar}$ geochronology. Geochimica et Cosmochimica Acta, 74(18), 5349-5367. https://doi.org/10.1016/J.GCA.2010.06.017

Rioux, M., Bowring, S., Kelemen, P., Gordon, S., Miller, R., \& Dudás, F. (2013). Tectonic development of the Samail ophiolite: High-precision $\mathrm{U}-\mathrm{Pb}$ zircon geochronology and Sm-Nd isotopic constraints on crustal growth and emplacement. Journal of Geophysical Research - Solid Earth, 118(5), 2085-2101. https://doi.org/10.1002/jgrb.50139

Rioux, M., Garber, J., Bauer, A., Bowring, S., Searle, M., Kelemen, P., \& Hacker, B. (2016). Synchronous formation of the metamorphic sole and igneous crust of the Semail ophiolite: New constraints on the tectonic evolution during ophiolite formation from high-precision U$\mathrm{Pb}$ zircon geochronology. Earth and Planetary Science Letters, 451, 185-195. https://doi.org/10.1016/j.epsl.2016.06.051

Roy, D. K., Acharyya, S. K., Ray, K. K., Lahiri, T. C., \& Sen, M. K. (1988). Nature of occurrence and depositional environment of the oceanic pelagic sediments associated with the ophiolite assemblage, South Andaman Island. Indian Minerals, 42, 31-56.

Saha, A., Dhang, A., Ray, J., Chakraborty, S., \& Moecher, D. (2010). Complete preservation of ophiolite suite from South Andaman, India: A mineral-chemical perspective. Journal of Earth System Science, 119(3), 365-381. https://doi.org/10.1007/s12040-010-0017-6

Sarma, D. S., Jafri, S. H., Fletcher, I. R., \& McNaughton, N. J. (2010). Constraints on the tectonic setting of the Andaman ophiolites, Bay of Bengal, India, from SHRIMP U-Pb zircon geochronology of plagiogranite. The Journal of Geology, 118(6), 691-697. https://doi.org/ $10.1086 / 656354$

Sengupta, S., Ray, K. K., \& Acharyya, S. K. (1990). Nature of ophiolite occurrences along the eastern margin of the Indian Plate and their tectonic significance. Geology, 18(5), 439-442. https://doi.org/10.1130/0091-7613(1990)018<0439

Shapiro, M. N., \& Solov'ev, A. V. (2009). Formation of the Olyutorsky-Kamchatka foldbelt: A kinematic model. Russian Geology and Geophysics, 50(8), 668-681. https://doi.org/10.1016/J.RGG.2008.10.006

Singh, A. K., Chung, S.-L., Bikramaditya, R. K., \& Lee, H. Y. (2017). New U-Pb zircon ages of plagiogranites from the Nagaland-Manipur ophiolites, Indo-Myanmar orogenic belt, NE India. Journal of the Geological Society, 174(1), 170-179. https://doi.org/10.1144/ jgs2016-048

Singh, S. C., Moeremans, R., McArdle, J., \& Johansen, K. (2013). Seismic images of the sliver strike-slip fault and back thrust in the Andaman-Nicobar region. Journal of Geophysical Research - Solid Earth, 118(10), 5208-5224. https://doi.org/10.1002/jgrb.50378

Solomon, M. (1990). Subduction, arc reversal, and the origin of porphyry copper-gold deposits in island arcs. Geology, 18(7), 630-633. https://doi.org/10.1130/0091-7613(1990)018<0630:SARATO >2.3.CO;2

Soret, M., Agard, P., Dubacq, B., Plunder, A., \& Yamato, P. (2017). Petrological evidence for stepwise accretion of metamorphic soles during subduction infancy (Semail ophiolite, Oman and UAE). Journal of Metamorphic Geology, 35(9), 1051-1080. https://doi.org/10.1111/ jmg. 12267

Soret, M., Agard, P., Dubacq, B., Vitale-Brovarone, A., Monié, P., Chauvet, A., et al. (2016). Strain localization and fluid infiltration in the mantle wedge during subduction initiation: Evidence from the base of the New Caledonia ophiolite. Lithos, 244, 1-19. https://doi.org/ 10.1016/j.lithos.2015.11.022

Stern, R. J. (2004). Subduction initiation: Spontaneous and induced. Earth and Planetary Science Letters, 226(3-4), 275-292. https://doi.org/ 10.1016/j.epsl.2004.08.007

Stern, R. J., \& Gerya, T. (2017). Subduction initiation in nature and models: A review. Tectonophysics, (October, 746, 173-198. https://doi. org/10.1016/j.tecto.2017.10.014

Stern, R. J., Reagan, M. K., Ishizuka, O., Ohara, Y., \& Whattam, S. A. (2012). To understand subduction initiation, study forearc crust: To understand forearc crust, study ophiolites. Lithosphere, 4(6), 469-483. https://doi.org/10.1130/L183.1

Syracuse, E. M., \& Abers, G. A. (2006). Global compilation of variations in slab depth beneath arc volcanoes and implications. Geochemistry, Geophysics, Geosystems, 7(5), n/a-n/a. https://doi.org/10.1029/2005GC001045

Tate, G. W., McQuarrie, N., van Hinsbergen, D. J. J., Bakker, R. R., Harris, R., \& Jiang, H. (2015). Australia going down under: Quantifying continental subduction during arc-continent accretion in Timor-Leste. Geosphere, 11(6), 1860-1883. https://doi.org/10.1130/ GES01144.1

Vaes, B., van Hinsbergen, D. J. J., \& Boschman, L. M. (2019). Reconstruction of subduction and back-arc spreading in the NW Pacific and Aleutian Basin: Clues to causes of Cretaceous and Eocene plate reorganizations. Tectonics, 38(4), 1367-1413. https://doi.org/10.1029/ 2018TC005164

van Hinsbergen, D. J. J., Maffione, M., Plunder, A., Kaymakcı, N., Ganerød, M., Hendriks, B. W. H., et al. (2016). Tectonic evolution and paleogeography of the Kırşehir Block and the Central Anatolian ophiolites, Turkey. Tectonics, 35(4), 983-1014. https://doi.org/10.1002/ 2015TC004018.Received 
van Hinsbergen, D. J. J., Peters, K., Maffione, M., Spakman, W., Guilmette, C., Thieulot, C., et al. (2015). Dynamics of intraoceanic subduction initiation: 2 . Suprasubduction zone ophiolite formation and metamorphic sole exhumation in context of absolute plate motions Geochemistry, Geophysics, Geosystems, 16(6), 1771-1785. https://doi.org/10.1002/2015GC005745

von Hagke, C., Philippon, M., Avouac, J. P., \& Gurnis, M. (2016). Origin and time evolution of subduction polarity reversal from plate kinematics of Southeast Asia. Geology, 44(8), 659-662. https://doi.org/10.1130/G37821.1

Wakabayashi, J., \& Dilek, Y. (2000). Spatial and temporal relationships between ophiolites and their metamorphic soles: A test of models of forearc ophiolite genesis. Geological Society of America Special Papers, 349(January), 53-64. https://doi.org/10.1130/0-8137-2349-3.53

Wakabayashi, J., \& Dilek, Y. (2003). What constitute "emplacement" of an ophiolite?: Mechanisms and relationship to subduction initiation and formation of metamorphic soles. Geological Society, London, Special Publications, 218(1), 427-447. https://doi.org/10.1144/GSL. SP.2003.218.01.22

Wang, J. G., Wu, F. Y., Tan, X. C., \& Liu, C. Z. (2014). Magmatic evolution of the Western Myanmar Arc documented by U-Pb and Hf isotopes in detrital zircon. Tectonophysics, 612-613, 97-105. https://doi.org/10.1016/j.tecto.2013.11.039

White, R. W., Powell, R., \& Clarke, G. L. (2002). The interpretation of reaction textures in Fe-rich metapelitic granulites of the Musgrave Block, Central Australia: Constraints from mineral equilibria calculations in the system. Journal of Metamorphic Geology, 20(1), 41-55. https://doi.org/10.1046/j.0263-4929.2001.00349.x

White, R. W., Powell, R., Holland, T. J. B., Johnson, T. E., \& Green, E. C. R. (2014). New mineral activity-composition relations for thermodynamic calculations in metapelitic systems. Journal of Metamorphic Geology, 32(3), 261-286. https://doi.org/10.1111/jmg.12071

Whitney, D. L., \& Evans, B. W. (2010). Abbreviations for names of rock-forming minerals. American Mineralogist, 95(1), 185-187. https:// doi.org/10.2138/am.2010.3371

Woodcock, N. H., \& Robertson, A. H. F. (1977). Origins of some ophiolite-related metamorphic rocks of the "Tethyan" belt. Geology, 5(6), 373-376. https://doi.org/10.1130/0091-7613(1977)5<373

Zhang, X., Chung, S.-L., Lai, Y.-M., Ghani, A. A., Murtadha, S., Lee, H.-Y., \& Hsu, C.-C. (2019). A 6000-km-long Neo-Tethyan arc system with coherent magmatic flare-ups and lulls in South Asia. Geology, 47(6), 573-576. https://doi.org/10.1130/g46172.1

Zhou, X., Li, Z. H., Gerya, T. V., Stern, R. J., Xu, Z., \& Zhang, J. (2018). Subduction initiation dynamics along a transform fault control trench curvature and ophiolite ages. Geology, 46(7), 607-610. https://doi.org/10.1130/G40154.1 